\title{
The application of satellite differential SAR interferometry-derived ground displacements in hydrogeology
}

\author{
Devin L. Galloway • Jörn Hoffmann
}

\begin{abstract}
The application of satellite differential synthetic aperture radar (SAR) interferometry, principally coherent (InSAR) and to a lesser extent, persistent-scatterer (PSI) techniques to hydrogeologic studies has improved capabilities to map, monitor, analyze, and simulate groundwater flow, aquifer-system compaction and land subsidence. A number of investigations over the previous decade show how the spatially detailed images of ground displacements measured with InSAR have advanced hydrogeologic understanding, especially when a time series of images is used in conjunction with histories of changes in water levels and management practices. Important advances include: (1) identifying structural or lithostratigraphic boundaries (e.g. faults or transitional facies) of groundwater flow and deformation; (2) defining the material and hydraulic heterogeneity of deforming aquifer-systems; (3) estimating system properties (e.g. storage coefficients and hydraulic conductivities); and (4) constraining numerical models of groundwater flow, aquifer-system compaction, and land subsidence. As a component of an integrated approach to hydrogeologic monitoring and characterization of unconsolidated alluvial groundwater basins differential SAR interferometry contributes unique information that can facilitate improved management of groundwater resources.
\end{abstract}

Résumé L'application de l'interférométrie différentielle radar à synthèse d'ouverture (SAR en anglais), principale-

Received: 8 May 2006 / Accepted: 9 October 2006

(C) Springer-Verlag 2006

Future satellite SAR missions specifically designed for differential interferometry will enhance these contributions.

D. L. Galloway (

US Geological Survey,

Modoc Hall Ste. 3005, 3020 State Univ. Dr. E.,

Sacramento, CA 95819, USA

e-mail: dlgallow@usgs.gov

Tel.: +1-916-2789549

Fax: +1-916-2789546

\section{J. Hoffmann}

German Aerospace Center,

German Remote Sensing Data Center,

Oberpfaffenhofen,

82234 Wessling, Germany ment cohérent (InSAR en anglais) et dans une moindre mesure, des techniques "persistent-scatterer" (PSI en anglais), aux études hydrogéologiques, ont amélioré les capacités à cartographier, surveiller, analyser et simuler l'écoulement des eaux souterraines, la compaction des systèmes aquifères et les subsidences de terrain. Un certain nombre d'investigations menées durant les dernières décennies montre comment les images spatialement détaillées des déplacements du sol mesurées avec l'InSAR, permettent de mieux comprendre l'hydrogéologie, particulièrement lorsque une série d'images est utilisée parallèlement à des chroniques historiques du changement des niveaux d'eau et des méthodes de gestion. Les avancées importantes comprennent: (1) l'identification structurelle ou lithostratigraphique des limites (par ex. les failles ou changement de faciès) de l'écoulement souterrain et de la déformation; (2) la définition de l'hétérogénéité matérielle et hydraulique des systèmes aquifères déformés; (3) l'estimation des propriétés du système (par ex. les coefficients d'emmagasinement et les conductivités hydrauliques); et (4) la contrainte des modèles numériques de l'écoulement des eaux souterraines, de la compaction des systèmes aquifères, et de la subsidence des sols. En tant que composante d'une approche intégrée de la surveillance hydrogéologique et de la caractérisation des bassins hydrogéologiques constitués d'alluvions non-consolidés, l'interférométrie différentielle SAR fournit une information unique qui peut aider à améliorer la gestion de la ressource en eaux souterraines. Les futures missions satellite SAR spécifiquement montées pour l'interférométrie différentielle, permettront de préciser ces contributions.

Resumen La aplicación de interferometría de radar satelital diferencial sintético de apertura (SAR), principalmente coherente $(\operatorname{lnSAR})$, y en menor extensión, de técnicas de dispersión persistente (PSI) en estudios hidrogeológicos ha mejorado las capacidades de mapeo, monitoreo, análisis, y simulación de flujo de agua subterránea, compactación de sistema de acuífero y hundimiento del terreno. Varias investigaciones de la década pasada muestran como las imágenes espaciales detalladas de desplazamientos del terreno medidos con lnSAR han aumentado el entendimiento hidrogeológico, especialmente cuando se usa una serie de tiempo de imágenes en conjunto con registros de cambios en niveles 
de agua y prácticas de gestión. Los avances importantes incluye: (1) identificación de límites litoestratigráficos o estructurales (por ejemplo, fallas o facies transicionales) de flujo de agua subterránea y deformación; (2) definición del material y heterogeneidad hidráulica de sistemas de acuíferos en deformación; (3) estimación de propiedades del sistema (por ejemplo, coeficientes de almacenamiento y conductividades hidráulicas); y (4) delimitacion de modelos numéricos de flujo de agua subterránea, compactación de sistema de acuífero, y hundimiento del terreno. Como un componente de un enfoque integrado de monitoreo y caracterización hidrogeológica de cuencas de agua subterránea aluviales no consolidadas la interferometría diferencial SAR contribuye información única que puede facilitar la gestión mejorada de recursos de agua subterránea. Las misiones futuras satelitales SAR diseñadas específicamente para interferometría diferencial van a estimular estas contribuciones.

Keywords Remote sensing - Subsidence . Aquifer-system compaction · Groundwater flow · InSAR

\section{Introduction}

Sub-centimeter ground displacements measured at high spatial resolution over large areas can be achieved with satellite differential synthetic aperture radar (SAR) interferometry using coherent interferometric (InSAR; Massonnet and Feigl 1998; Rosen et al. 2000) and persistent or permanent scatterer (PSI; Ferretti et al. 2000, 2001) techniques. The application of these techniques in hydrogeologic research and monitoring within the past decade has led to improved characterization of the spatiotemporal responses of aquifer systems to hydro-mechanical stresses caused by changes in groundwater storage.

The purpose of this paper is three-fold: (1) to describe how InSAR-derived ground-displacements have enhanced understanding of groundwater flow systems; (2) to identify limitations of the techniques; and (3) to speculate on the future potential of SAR interferometry to support hydrogeologic research and monitoring. A number of examples are presented in brief, and four case study areas are presented in more detail. The focus is on groundwater flow systems and aquifer mechanics in particular, and though many of the processes and applications discussed also are relevant to the production of hydrocarbons and hydrothermal fluids from subsurface reservoirs, they are not discussed in this paper.

A review of emerging InSAR applications in hydrology and geomorphology found that some of the techniques were largely overlooked by the geographic and radar communities, and that the ability of InSAR to provide useful information to hydrologists and geomorphologists has been under-recognized (Smith 2002). Hydrogeologists have been relatively slow to use satellite remote sensing in their studies, attributed, in part, to the divide between the research community driving the instrument development and operation, and the hydrogeologic research community (Hoffmann 2005).

Despite these obstacles, SAR is one remote sensing data product that has contributed to new developments in hydrogeology. The surface displacement measurements from InSAR and PSI over unconsolidated alluvial aquifer systems have spurred renewed interest in aquifer mechanics. Many studies have demonstrated that surface displacements related to aquifer-system deformation accompanying groundwater discharge and recharge are not only common, but can be measured reliably in spatial and temporal detail (e.g. Galloway et al. 1998; Amelung et al. 1999; Hoffmann et al. 2001, 2003a; Watson et al. 2002; Schmidt and Bürgmann 2003; Ferretti et al. 2004; Canuti et al. 2005).

SAR interferometry, particularly InSAR, has improved hydrogeologic understanding in several key areas: identifying groundwater flow barriers; characterizing seasonal land-surface motion; estimating aquifer-system storage and flow properties; and, providing additional constraints to numerical groundwater flow models. Previously unknown and poorly defined structural or lithostratigraphic controls on groundwater flow and (or) aquifer-system deformation have been identified and defined (e.g. Amelung et al. 1999; Galloway et al. 2000a; Bawden et al. 2001; Lu and Danskin 2001; Valentine et al. 2001; Bell et al. 2002; Buckley et al. 2003; Schmidt and Bürgmann 2003). Seasonal variations of land subsidence and uplift accompanying seasonal climatic and water-use variations have been measured (e.g. Amelung et al. 1999; Galloway et al. 2000a; Bawden et al. 2001; Hoffmann et al. 2001; Lu and Danskin 2001; Watson et al. 2002; Colesanti et al. 2003; Schmidt and Bürgmann 2003). InSAR measurements have been used to estimate groundwater flow storage and hydraulic conductivity properties (Hoffmann et al. 2001, 2003a; Halford et al. 2005), and to constrain groundwater flow and subsidence simulation models (e.g. Hoffmann et al. 2003a; Hanson et al. 2004; Halford et al. 2005).

\section{Improved mapping, monitoring, and analysis of deforming aquifer systems using satellite differential SAR interferometry}

The Panel on Land Subsidence of the US National Research Council (NRC; 1991) recognized three information needs:

"First, basic earth-science data and information on the magnitude and distribution of subsidence (...) to recognize and to assess future problems. These data (...) help not only to address local subsidence problems but to identify national problems. (...) Second, research on subsidence processes and engineering methods for dealing with subsidence (...) for cost-effective damage prevention or control. (...) And third, although many types of mitigation methods are in use in the United 
States, studies of their cost-effectiveness would facilitate choices by decision makers."

A variety of ground- and satellite-based methods is used to measure aquifer-system compaction and land subsidence (Table 1). SAR interferometry is ideally suited to measure the spatial extent and magnitude of surface deformation associated with aquifer-system compaction. InSAR can provide millions of data points in a region covering an entire aquifer system and is often less expensive than obtaining sparse point measurements from labor-intensive spirit-leveling and global positioning system (GPS) surveys. By identifying specific areas of deformation within broader regions of interest, SAR interferometry also can be used to site and coordinate local and regional-scale subsidence monitoring (e.g. borehole extensometers, GPS networks, and leveling lines; Bawden et al. 2003). These attributes of SAR interferometry, particularly InSAR, address each of the information needs identified by the NRC. Another important attribute of SAR interferometry is the increasing historical SAR data archive. For many areas, substantial data sets exist from the early 1990s, enabling measurements of historic surface displacements in this time period. In addition, new acquisitions can be ordered as needed. The detailed procedure and cost depends on the sensor.

\section{InSAR}

Differential InSAR, or for purposes of this discussion "InSAR", can deliver detailed measurements of largescale ground deformations associated with earthquakes, volcanoes, aquifer systems, landslides, etc. (Massonnet and Feigl 1998). Compared to traditional geodetic methods, InSAR presents a cost-effective way of obtaining spatially detailed, high-resolution land-surface dis- placements. Many examples exist and their results offer unique input to strain models and support the understanding of the underlying deformation processes. InSAR measures ground displacements. The displacement is encoded in the phase difference between two SAR images that can be measured at each point (pixel) of the phasedifference image, commonly termed an interferogram. An interferogram is created from two SAR images with very similar imaging geometries. The two images are precisely coregistered before the phase difference is computed for each pixel. As the dominant signal in most interferograms is the signal due to the topographic variation imaged from different orbital positions (Zebker and Goldstein 1986), this is reduced either using another interferogram or a digital elevation model (DEM). The remaining "differential" phase $(\phi)$ contains contributions due to surface displacement $\left(\phi_{\text {disp }}\right)$, changes in atmospheric conditions (temperature, moisture content, pressure $-\phi_{\text {atmo }}$ ), residual topographic signal due to incomplete or inaccurate removal of the topographic phase contribution $\left(\phi_{\Delta \text { topo }}\right)$ and noise effects due to limited signal power of the SAR instrument or unmodeled changes of surface properties $\left(\phi_{n}\right)$ :

$\phi=\phi_{\text {disp }}+\phi_{\text {atmo }}+\phi_{\Delta \text { topo }}+\phi_{\mathrm{n}}$.

Because interferometric displacement analyses use Eq. (1) to estimate the displacement phase, which is then converted to range displacement in the direction of the sensor's line-of-sight (LOS), the terms $\phi_{\text {atmo }}, \phi_{\Delta \text { topo }}$, and $\phi_{\mathrm{n}}$ must be considered contributions to the measurement error. The atmospheric phase can introduce errors corresponding to surface displacements of up to a few centimeters, particularly in hot and humid climates. However, atmospheric signal contributions generally are not repeated in independent interferograms. Where multiple observations are available, gross misinterpretations of

Table 1 Select methods of measuring aquifer-system compaction and land subsidence (modified from Galloway et al. 2000b)

\begin{tabular}{|c|c|c|c|c|}
\hline Method & Component displacement & Resolution $^{\mathrm{a}}(\mathrm{mm})$ & Spatial density $^{\mathrm{b}}$ (samples/survey) & Spatial scale \\
\hline Spirit level & Vertical & $0.1-1$ & $10-100$ & Line-network \\
\hline Geodimeter & Horizontal & 1 & $10-100$ & Line-network \\
\hline Borehole extensometer ${ }^{\mathrm{c}}$ & Vertical & $0.01-0.1$ & $1-3$ & Point \\
\hline \multicolumn{5}{|l|}{ Horizontal extensometer } \\
\hline Tape & Horizontal & 0.3 & $1-10$ & Line-array \\
\hline Invar wire & Horizontal & $10^{-4}$ & 1 & Line \\
\hline Quartz tube & Horizontal & $10^{-5}$ & 1 & Line \\
\hline \multirow[t]{2}{*}{ GPS } & Vertical & 20 & $10-100$ & Network \\
\hline & Horizontal & 5 & & \\
\hline Satellite SAR interferometry & & & & \\
\hline InSAR & Range & $1-10$ & $10^{5}-10^{7}$ & Map pixel ${ }^{\mathrm{e}}$ \\
\hline PSI & Range & 1 & Variable $^{\mathrm{d}}$ & Map pixel ${ }^{\mathrm{e}}$ \\
\hline
\end{tabular}

${ }^{a}$ Measurement resolution obtained under optimum conditions

${ }^{\mathrm{b}}$ Number of measurements generally necessary to define the distribution and magnitude of land subsidence at the scale of the survey

${ }^{\mathrm{c}}$ Counter-weighted pipe extensometer (Riley 1969)

${ }^{\mathrm{d}}$ Depends on presence of permanent scatterers

${ }^{\mathrm{e}}$ A pixel (picture element) on an InSAR/PSI displacement map based on existing spaceborne sensors is typically 40-80-m resolution 
atmospheric signals can be avoided (e.g. Massonnet and Feigl 1998). The importance of $\phi_{\Delta \text { topo }}$ depends on the accuracy of the available topographic information, e.g. the $\mathrm{DEM}$, and the interferometric baseline - a function of the orbital geometries. Sedimentary aquifer systems often are characterized by relatively flat topography and the resulting phase error due to uncompensated topography is rarely large. However, local deviations of the imaged surface from the DEM, e.g. due to large buildings or earth works, can cause phase variations that add to the noise in the interferogram. Finally, the noise term in Eq. (1) primarily depends on the signal-to-noise ratio governed by (1) the signal power of the instrument, (2) the radarreflectivity of the surface, and (3) the coherent fraction of energy between the two SAR images (known as the interferometric coherence). Generally, the limiting factor is the interferometric coherence, which depends on the orbital distance between the two acquisition tracks projected into the LOS (termed the interferometric baseline) and on the amount of temporal change (vis-à-vis the radar wavelength) occurring between the two acquisitions.

Temporal variability frequently prohibits interferometric analyses, particularly for vegetated or agricultural areas. It is extremely difficult to predict the coherence a priori for all but the most barren or densely vegetated surfaces. Currently, observations are routinely made over fallow, sparsely vegetated areas typically in arid regions, and over urban areas with large populations of stable reflectors.

\section{Persistent scatterer interferometry (PSI)}

Persistent (also known as permanent) scatterer interferometry (PSI) uses a different approach than InSAR for processing SAR imagery, and has been shown to overcome some of the limitations of the InSAR technique. PSI (Ferretti et al. 2000, 2001) involves the processing of numerous, typically more than 30 , interferograms to identify a network of persistent, temporally stable, highly reflective ground features-permanent scatterers. These scatterers typically are cultural features of the developed landscape such as buildings, utility poles, roadways, etc. The phase history of each scatterer is extracted by estimating a predefined displacement model (typically a linear, constant-rate model) to provide interpolated maps of average annual displacements, or the displacement history, up to the length of a SAR data archive, of each individual scatterer, thus providing a "virtual" GPS network with "instant" history. By focusing on temporally stable targets in the image, temporal decorrelation is avoided or strongly reduced. Furthermore, most of the strong and stable reflectors identified represent small individual scattering elements. For this type of scatterer though, a larger fraction of the reflected energy remains coherent for larger interferometric baselines, allowing a larger set of SAR scenes to be used in the analysis. Finally, the large number of observations available in a typical SAR data set used in a PSI analysis supports a statistical analysis of the observed phase histories in space and time, and depending on the characteristics of the displacements, it is often possible to separate the phase differences caused by atmospheric variations and uncompensated topography - $\phi_{\text {atmo }}$ and $\phi_{\Delta \text { topo }}$ in Eq. (1) - from those due to surface displacements.

PSI has been applied primarily in urban environments, where the density of stable scatterers (e.g. buildings, roadways, poles, etc.) typically is quite high (as many as a few hundred per square kilometer). Over natural terrain, the paucity of stable targets severely limits PSI's successful application. A small number of investigations have demonstrated a successful application of PSI in "rural" terrain (Usai 2001; Kircher 2004). However, the investigations in the Netherlands and western Germany, used stable targets such as houses and other man-made features that were present in sufficient numbers. Hooper et al. (2004) have proposed a modified algorithm for natural terrain, but this has been demonstrated for relatively dry conditions and it is questionable whether their approach will work over agricultural areas prone to temporal decorrelation owing to variable moisture and crop conditions.

The PSI technique is a relatively recent development that can reduce the principal errors inherent in InSAR processing methods - errors caused by temporal and geometrical decorrelation and atmospheric artifacts. A potentially severe limitation of PSI, particularly where scatterer density is small and displacement magnitudes are large, is the necessity to determine a motion model a priori, which is used in resolving phase ambiguities. Another limitation of PSI is the difficulty of identifying stable targets in rural and agricultural areas. Consequently, the majority of PSI applications have focused on urban areas - e.g. Paris, France (Fruneau and Sarti 2000); San Francisco Bay Area, USA (Ferretti et al. 2004); Bangkok, Thailand (Worawattanamateekul et al. 2004); Phoenix, USA (Beaver et al. 2005); Arno River Basin-Florence, Italy; (Canuti et al. 2005); Berlin, Germany and Las Vegas, USA (Kampes 2005); London (NPA 2006).

\section{Case studies}

The application of satellite differential SAR interferometry to land subsidence caused by aquifer-system compaction has improved our recognition of current subsidence problems and understanding of aquifer-system compaction processes. This information is proving useful to stakeholders attempting to balance the present-day and projected use of groundwater resources with the accompanying subsidence hazards in susceptible aquifer systems. Selected examples of InSAR mapping, monitoring, and analysis of aquifer-system compaction and land subsidence follow. Although many PSI investigations have observed motion attributed to deforming aquifer systems, there are relatively few examples of in-depth hydrogeologic interpretations of the results to date. Hence, the following examples in the USA highlight InSAR applications. 
Antelope Valley, Mojave Desert, California

Antelope Valley was one of the first areas where InSAR was used to detect and map aquifer-system compaction and constrain simulations of groundwater flow and aquifer-system compaction (Fig. 1; Galloway et al. 1998; Hoffmann et al. 2003a). The InSAR-derived ground displacements were "ground-truthed" using historical geodetic and hydrogeologic information, concurrent measurements of aquifer-system compaction, and simulations of groundwater flow and aquifer-system compaction. Hydrogeologic information was obtained from the correlation between observed spatial and temporal trends of subsidence and groundwater levels, and the mapped distribution of hydrostratigraphic units.

Historical subsidence (1930-1992) measured using terrestrial geodetic techniques (spirit leveling and GPS) revealed a regional subsidence pattern (Fig. 1a) interpolated from a sparse network of benchmarks. A local subsidence maximum of nearly $2 \mathrm{~m}$ was attributed to aquifer-system compaction owing to groundwater withdrawals (Ikehara and Phillips 1994). Comparison of the regional historical subsidence patterns to InSAR displacement maps (interferograms) for the period 20 October 1993 to 1 May 1999 revealed regional-scale conformity with local-scale incongruities (Galloway et al. 1998; Hoffmann et al. 2003a).

Comparison of concurrent measurements of aquifersystem compaction measured at a borehole extensometer anchored $256 \mathrm{~m}$ below land surface (Holly site: established 1990) and land subsidence computed from an interferogram (assuming only vertical motion) for the period 20 October 1993 to 22 December 1995 revealed that the land subsidence computed from the interferogram was about 1.3 times the $31 \mathrm{~mm}$ of measured compaction at the extensometer (Galloway et al. 1998). This was in general agreement with results from geodetic surveys which suggested that subsidence at the Holly site was about 1.5 times the measured compaction at the extensometer, indicating that about $1 / 3$ of the subsidence could be attributed to compaction below the 256-m anchor depth. Good agreement was found between InSAR- and extensometer-derived displacement time series at two extensometers (Holly site and Lancaster site: established 1996 at 363-m anchor depth) based on 22 interferograms for the period 26 January 1996 to 1 May 1999 and compaction measured concurrently at those sites (Figs. 1b,c; Hoffmann et al. (2003a). The time-series at both extensometers show about $5 \mathrm{~mm}$ seasonal subsidence and uplift with some net annual subsidence; measurements at the Holly site support the earlier observation that some compaction is occurring below the anchor depth of the extensometer.

Galloway et al. (1998) simulated coupled groundwater flow and aquifer-system compaction in the Lancaster groundwater subbasin to determine whether the 20 October 1993 to 22 December 1995 interferogram could reasonably be explained by aquifer-system compaction. The model was constrained by available water-level, pumpage and aquifer-system compaction data. Onedimensional vertical deformation caused by changes in effective stress (Terzaghi 1925) related to changing water levels was simulated using the IBS1 Package (Leake and Prudic 1991) for the MODFLOW groundwater flow model (McDonald and Harbaugh 1988). IBS1 includes the assumption that pore fluid pressures within the aquitards equilibrate instantaneously with changes in head in the adjacent aquifers, i.e. the aquitards have small time constants. This is a reasonable simplifying approximation for thin aquitards. Estimates of the elastic and inelastic skeletal storage coefficients that govern the vertical
Fig. 1 Measured land subsidence and aquifer-system compaction, Antelope Valley, California (CA). a InSARdetected subsidence (October 1993 to December 1995) and historical (1930-1992) subsidence (Beige-colored areas signify regions of decorrelation of the radar; black-colored areas signify regions of small-magnitude uplift). InSAR-derived displacements and compaction measured at b the Holly extensometer site and $\mathbf{c}$ the Lancaster extensometer site, shown with groundwater levels measured in a nearby well (a modified from Galloway et al. 1998; $\mathbf{b}$ and $\mathbf{c}$ modified from Hoffmann et al. 2003a)
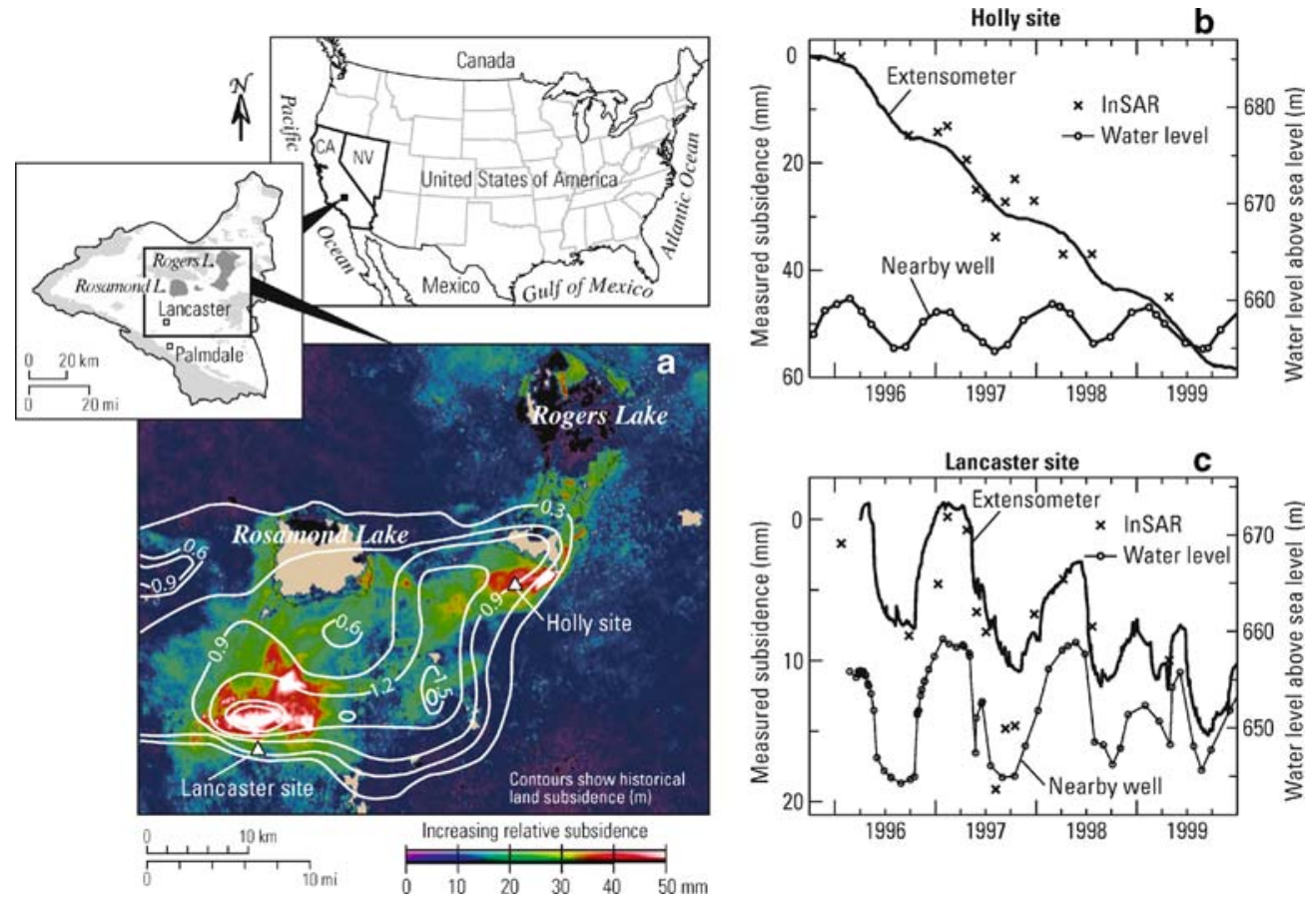
deformation of the aquifer system were constrained by previous estimates based on the compaction history of other alluvial aquifer systems in California (Helm 1978). Initial heads used in the simulation were based on measured water levels and equated to the previous maximum stresses (preconsolidation stresses). Thus, further head declines caused aquitards to compact inelastically, and instantaneously.

The subsidence areas indicated by InSAR were generally consistent with the model simulation indicating that the detected subsidence was the result of aquifersystem compaction. Subsidence residuals between the interferogram and the simulation were fairly small in the areas of maximum subsidence. Two areas of large negative residuals, one west of Rosamond Lake and another south of Lancaster, occurred where the simulation overestimated the amount of subsidence compared to the interferogram. Observed water-level declines in each area and the presence of mapped aquitards in one area suggested the presence of fine-grained units with small skeletal compressibilities and (or) large preconsolidation stresses, or thick aquitards subject to residual (delayed) compaction in these areas.

Spatially varying compaction time constants (3.8285 years $)$ and inelastic skeletal storage coefficients $(0$ 0.09 ; Fig. 2a) were estimated using inverse modeling constrained by historical terrestrial geodetic measurements and InSAR (Hoffmann et al. 2003a). The simulations were based on modifications of a previously calibrated regional model of groundwater flow and compaction (MODFLOW, IBS1; Leighton and Phillips 2003). Modifications to the Leighton and Phillips (2003) model consisted of substituting the SUB Package (Hoffmann et al. 2003b) for IBS1. The SUB Package accounts for the time delay accompa-
Fig. 2 Simulated subsidence and drawdown, Antelope Valley, California, 1996-1999. a Model-derived parameter values for compaction time constants and aquifer-system inelastic skeletal storage coefficients. b Simulated subsidence and data residuals (simulated minus InSARderived subsidence). Simulation overestimates the subsidence measured by InSAR. c Simulated drawdowns and kriged measured drawdowns. Disagreement between simulated and measured subsidence can be explained in part by poor agreement between simulated drawdowns and kriged measured drawdowns (modified from Hoffmann et al. 2003a)
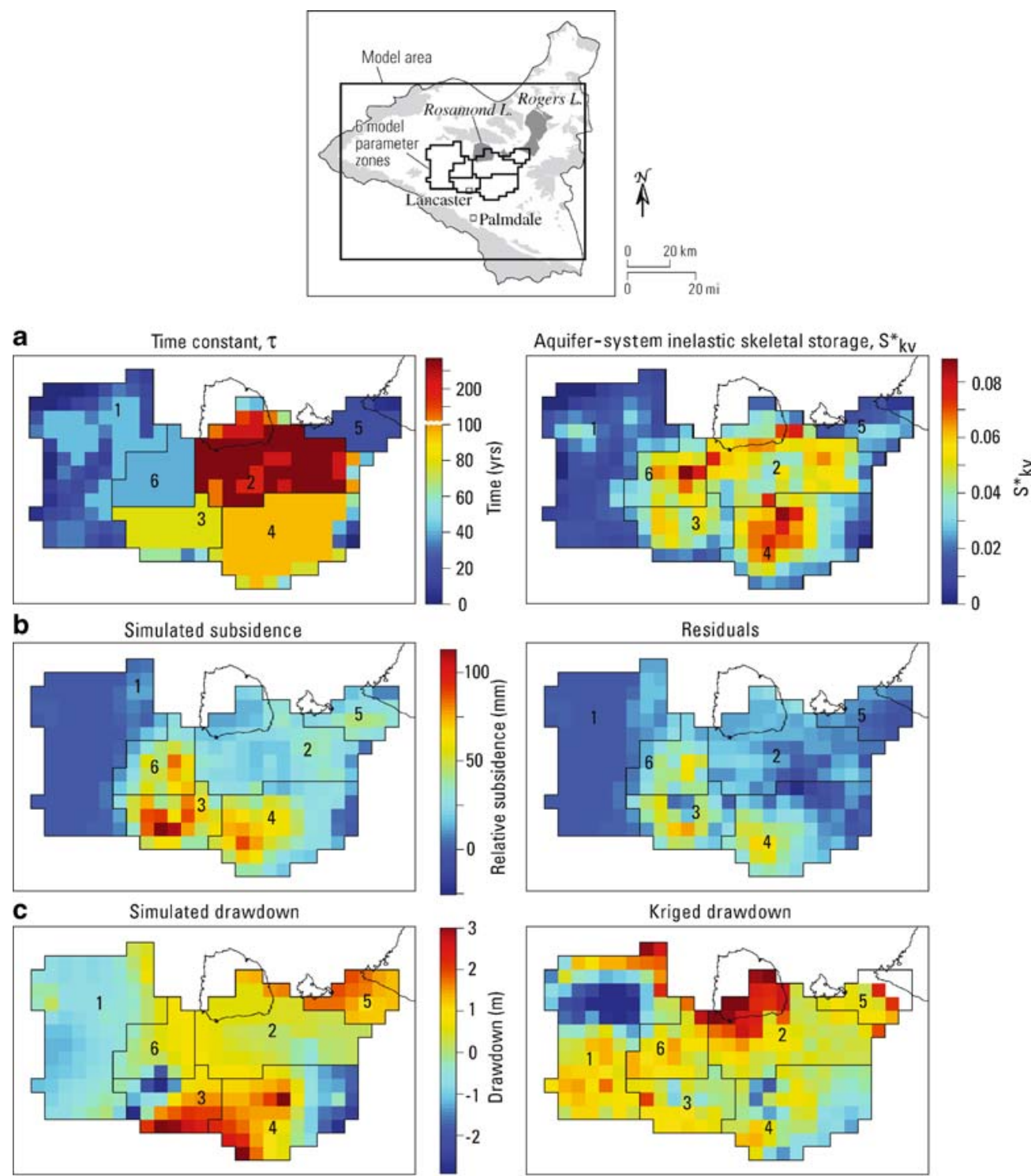

Kriged drawdown

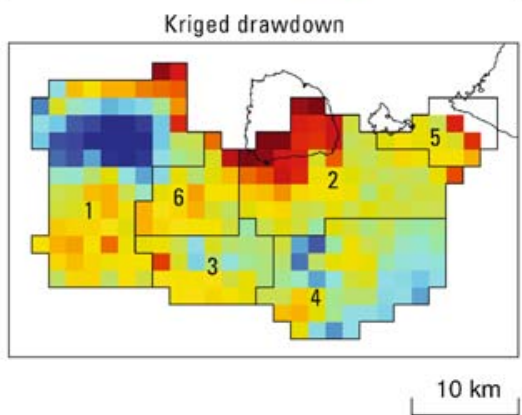


nying fluid-pressure diffusion and deformation in thick aquitards.

Though the resulting parameter estimates significantly improved agreement between the simulated and observed (measured) subsidence (Fig. 2b), the temporal coverage (3 yrs) of the SAR data was insufficient to constrain the large time constants associated with thick aquitards in Antelope Valley. However, InSAR was useful in mapping and monitoring subsidence, defining sub-regional zones of contrasting aquifer-system hydraulic properties (parameter zones) within the model, and estimating storage parameters where time constants are small. Simulated heads using subsidence as a constraint matched the long-term head changes better than short-term head fluctuations which strongly influence subsidence over short periods. The simulations revealed that the good agreement between the original model and observed long-term water-level changes was little affected by the modifications to account for the delayed release of groundwater from aquitard storage. Therefore, although delayed release from storage owing to compaction of thick aquitards may greatly affect the timing of associated subsidence, regional groundwater flow in Antelope Valley is relatively insensitive to this component of aquifer-system compaction.

\section{Las Vegas Valley, Nevada}

In Las Vegas Valley, hundreds of square kilometers have been affected by subsidence, which has been monitored since 1935 using terrestrial geodetic techniques. Locally about $1.7 \mathrm{~m}$ has been measured since 1963 (Bell et al. 2002; Fig. 3). Differential subsidence has been measured across Quaternary faults offsetting the basin-fill sediments, and associated earth fissures have been attributed to differential aquifer-system compaction. The surface dis- placements, ground failures and tilts are responsible for more than 10 million dollars in damage to housing and other civil infrastructures (Pavelko et al. 1999). InSARderived displacements for the period April 1992 to December 1997 (Fig. 4a; Amelung et al. 1999) revealed, more than previously recognized, that the spatial pattern and extent of subsidence was controlled by Quaternary faults. This is in contrast to the more spatially uniform subsidence patterns interpolated solely from the terrestrial geodetic networks (Fig. 3a) and simulated in a regional groundwater flow and subsidence model (Morgan and Dettinger 1996). Profiles derived from the interferograms (Fig 4b) showed a correspondence in the sense (magnitude and gradient) of displacement across the faults for time intervals measured during the period 1992-1997 compared with historical surveys (spirit leveling). The InSARderived profiles showed slower rates of differential subsidence since the 1980 s, with a pronounced slowing from 1992 to 1997.

The general shape of the InSAR subsidence feature is reasonably correlated with the intersection of a water-level change (decline) map (predevelopment to 1990) and a map of the aggregate clay thickness (Fig. 5a,c; Amelung et al. 1999). Temporal variability in the spatial extent and magnitude of the InSAR displacements showed that seasonal subsidence and uplift occurred in some places in response to seasonal drawdown and recovery suggesting some spatial variability in the elastic and inelastic storage properties of the aquifer system. The InSAR results indicated a slowing of subsidence rates from 1992 to 1999 that is attributed to groundwater level stabilization or recovery, in part related to an aquifer storage and recovery program in operation primarily in the central and northwestern parts of the basin since the early 1990s (Amelung et al. 1999; Bell et al. 2002).

Fig. 3 Historical subsidence, Las Vegas Valley, Nevada. a 1963-1987, showing three principal subsidence bowls mapped using leveling data for benchmarks and transects across faults. b 1963-2000, showing four principal subsidence bowls mapped using InSAR combined with GPS and conventional leveling data for benchmarks and transects across faults (modified from Bell et al. 2002)

a. 1963-1987 subsidence map based on leveling data

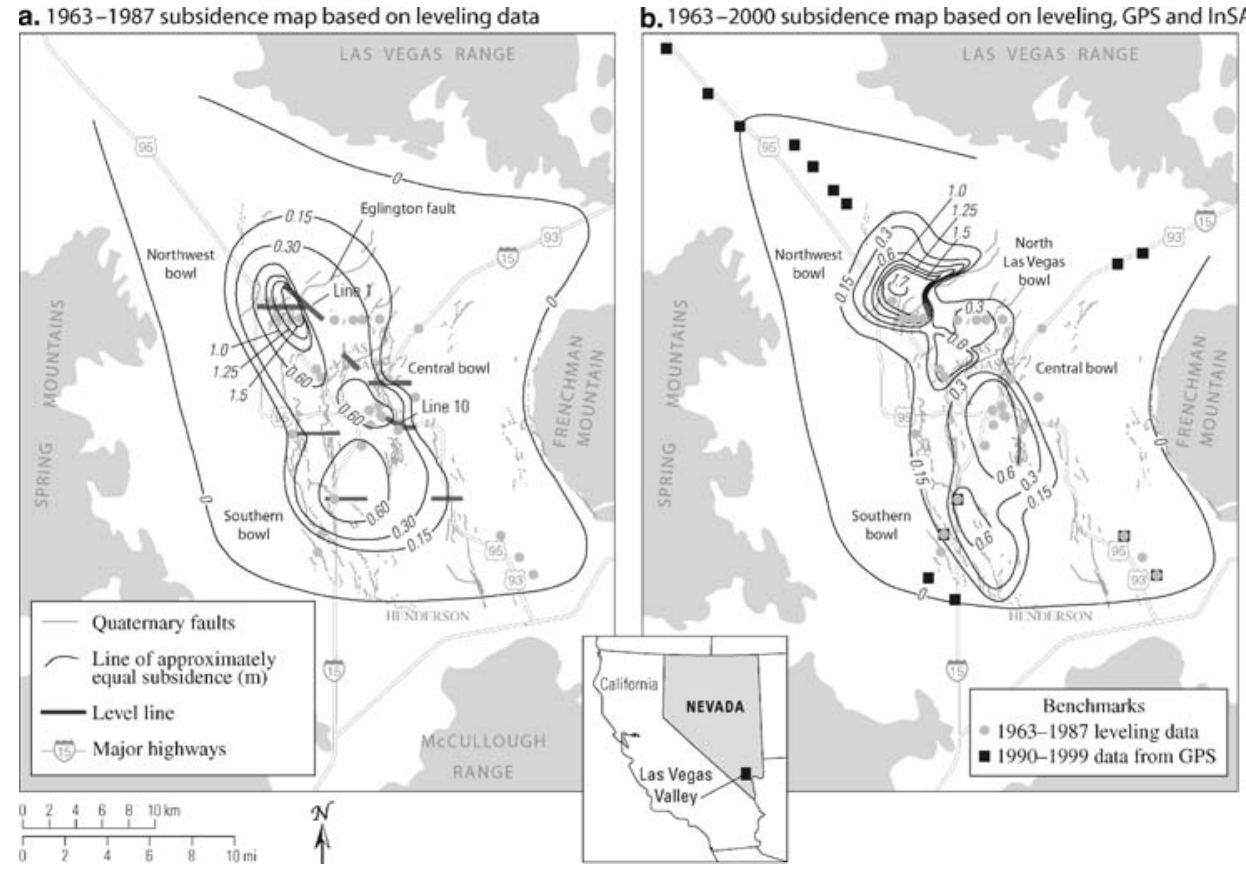


Fig. 4 InSAR-derived subsidence, Las Vegas Valley, Nevada. a April 1992 to December 1997. b Subsidence rates compared to historic leveling at lines 1 and 10 for given periods (month/year; modified from Amelung et al. 1999) a

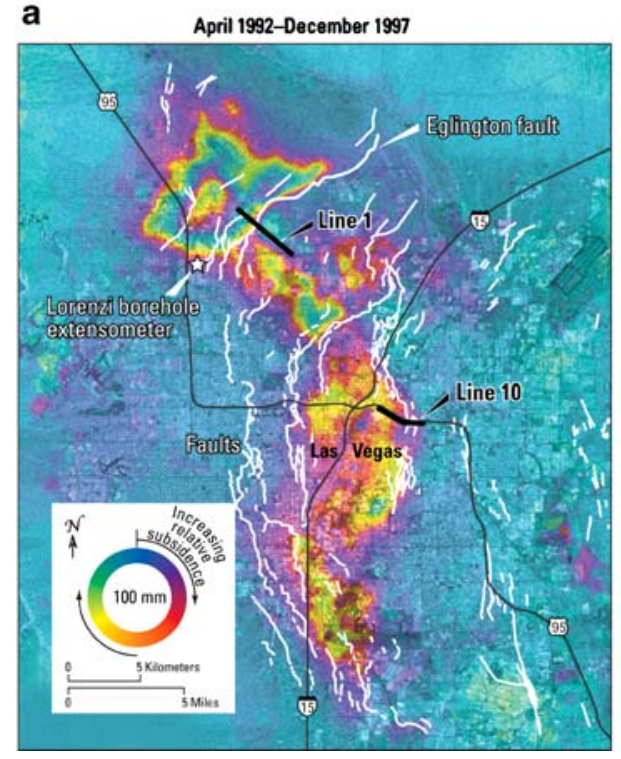

b

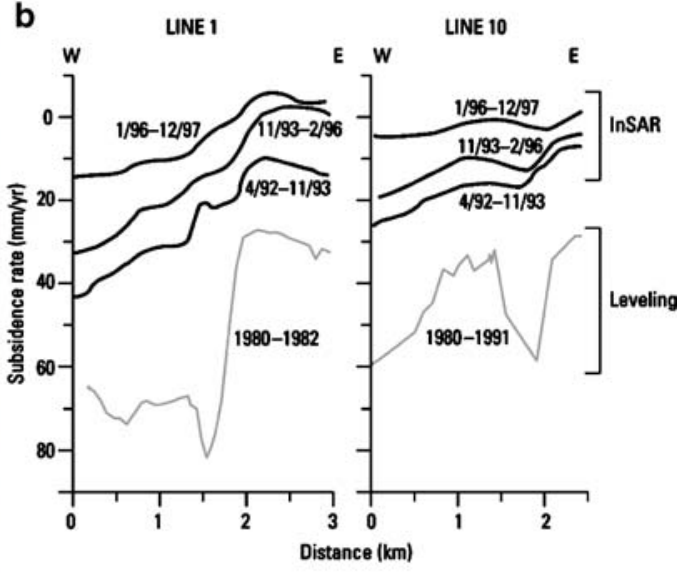

InSAR measurements derived from more than 40 interferograms from September 1992 to December 1999, highlight the small-magnitude, generally elastic (recoverable) deformations of the aquifer system that occur at seasonal time scales (Hoffmann et al. 2001; Pavelko et al. 2006). In many locations, especially the central Las Vegas Valley, displacements were consistent with elastic winter expansion (Fig. 6) and summer compression of the aquifer system in response to the recovery and drawdown of water levels. Estimates of the aquifer-system elastic skeletal storage coefficient $\left(S_{\mathrm{ke}}^{*}\right)$ were computed at six locations from the measured displacements and concurrent waterlevel changes in nearby wells (Hoffmann et al. 2001; Fig. 7). The values calculated for the well locations were within the range of elastic storage coefficients estimated on the basis of a one-dimensional inverse simulation of aquifer-system deformation constrained by the Lorenzi borehole extensometer data (Pavelko 2004), a calibrated regional three-dimensional groundwater flow model (Morgan and Dettinger 1996), and aquifer-test analyses (Malmberg 1965).

\section{Santa Clara Valley, California}

The northern Santa Clara Valley (Fig. 8) was the first area in the USA where subsidence owing to groundwater withdrawal was recognized (Tolman and Poland 1940). In the first half of the twentieth century, the Santa Clara Valley was intensively cultivated. By 1960, the valley was undergoing a transition from agricultural to urban land and water use, and about $246,700 \mathrm{~m}^{3}$ of groundwater was pumped annually to irrigate crops and meet growing urban water demands. By 1964, the water level in a well in San Jose had reached a historic low of $71 \mathrm{~m}$ below land surface and about $4 \mathrm{~m}$ of subsidence had occurred since 1910. Lands adjacent to the southern end of the San Francisco Bay subsided 0.6-2.6 m by 1969 placing 4,400 ha of dry land below high-tide level and creating costly coastal and riverine flood hazards (Ingebritsen and Jones 1999). Since the mid-1960s, imported surface-water has been used to supplement water demand, and recharge the groundwater system. Water levels in the confined aquifer system have recovered as much as $70 \mathrm{~m}$, and presently stand near their predevelopment levels in many
Fig. 5 Aggregate clay thickness and water-level change, Las Vegas Valley, Nevada superimposed on InSAR displacement map (April 1992December 1997) shown in Fig. 4a. a Water-level decline predevelopment period to 1990 ; b water-level rise 1990-1997; c aggregate clay thickness (modified from Amelung et al. 1999)
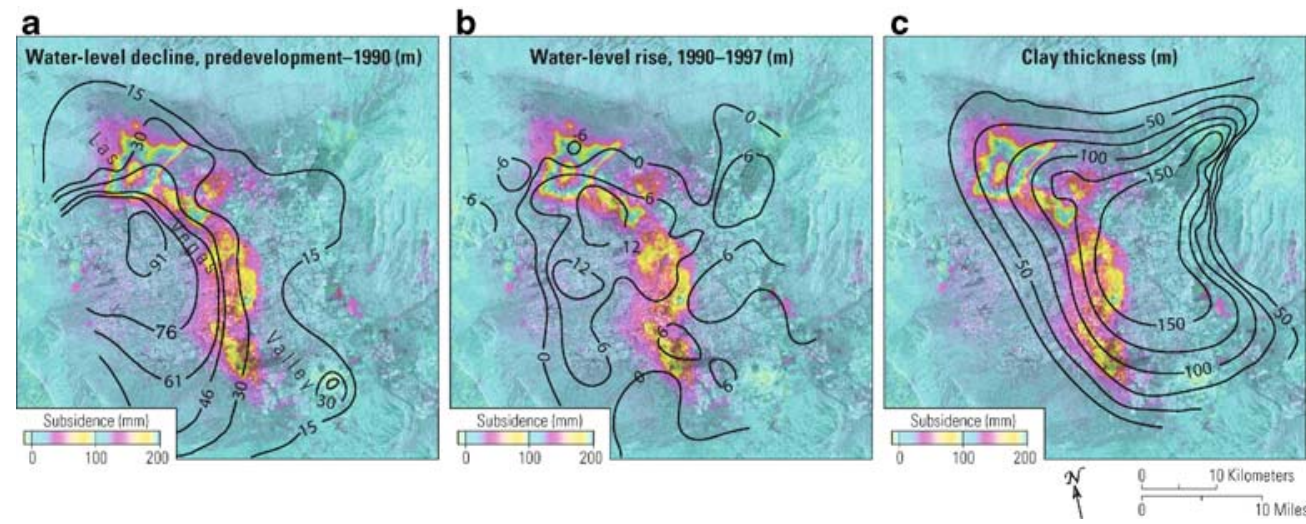
Fig. 6 Displacement patterns for two winter seasons, Las Vegas Valley, Nevada. a September 1992 to April 1993, and b October 1996 to May 1997. The dominant deformation observed is uplift in the central subsidence zone (area $A$ ). The subsidence in the northwest subsidence bowl (areas $B$ and $C$ ) has been significantly reduced during winter 1996-1997 (modified from Hoffmann et al. 2001)
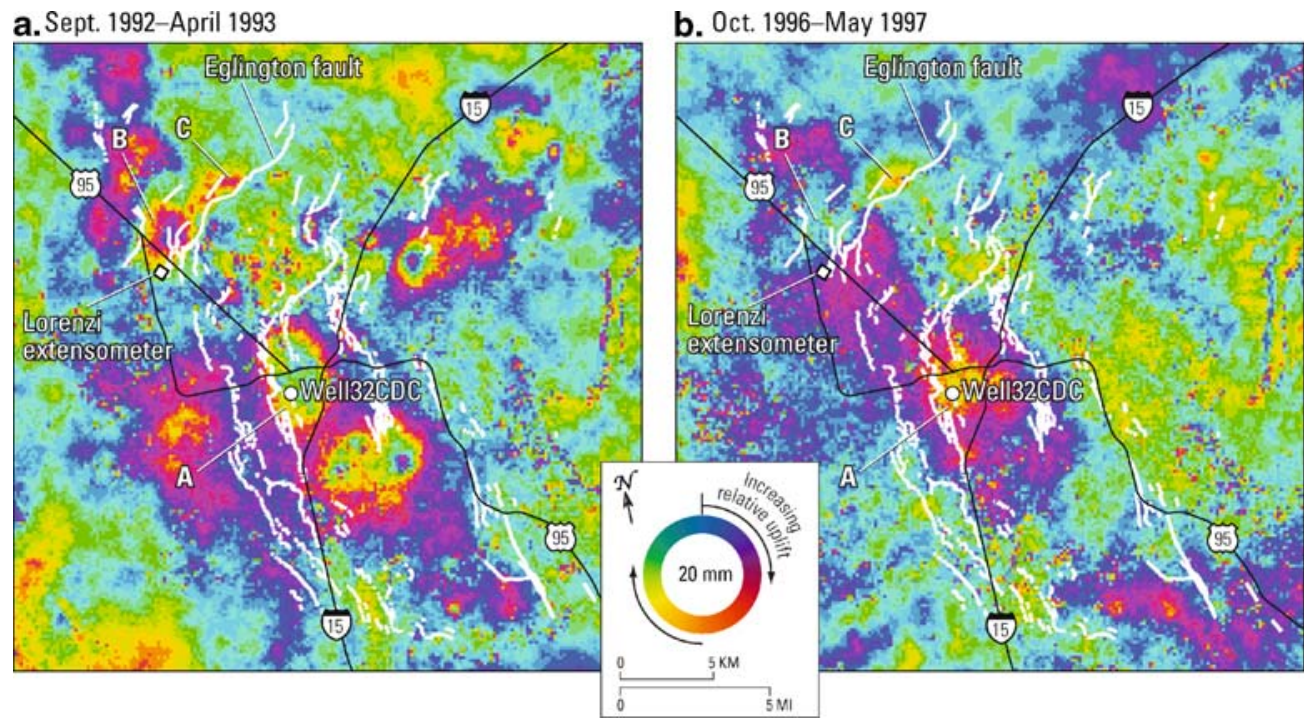

areas. Since 1969, careful management of the groundwater system has largely arrested subsidence in the valley.

Terrestrial geodetic surveys and borehole extensometer (e.g. SUNNY and MARTHA shown in Fig. 8) measurements since the 1970s show some small annual residual subsidence (Poland and Ireland 1988; Hanson et al. 2004). The extensometers and the InSAR-derived displacements show recoverable (elastic) seasonal subsidence and uplift as much as $30-40 \mathrm{~mm}$ west of the Silver Creek fault (Fig. 9) accompanying the annual cycle of groundwater discharge and recharge (Ikehara et al. 1998; Galloway et al. 2000a; Schmidt and Bürgmann 2003). InSAR-derived displacements for multi-annual periods (Fig. 10) show regional uplift possibly partitioned by the Silver Creek fault. InSAR time series along profiles $\mathrm{A}^{-\mathrm{A}^{\prime}}$ and $\mathrm{B}-\mathrm{B}^{\prime}$ (shown in Fig. 8) compared well with multi-annual elevation changes measured using spirit leveling (Schmidt and Bürgmann 2003).

The northeastern boundary of the InSAR-derived seasonal subsidence pattern is linear and subparallel to the
Fig. 7 Calculation of the elastic skeletal storage coefficient from stress-displacement analysis for two locations (shown in Fig. 6), Las Vegas Valley, Nevada. On the left are time series plots for water level measurements in meters below land surface and vertical displacements, shown as changes in vertical elevation (relative subsidence is positive) as measured in the interferograms. Each plus symbol $(+)$ corresponds to a radar acquisition. On the right, these data are plotted in a stress-displacement diagram. The inverse slope of the solid line is the weighted least squares estimate for the aquifer elastic skeletal storage coefficient $S_{\mathrm{ke}}{ }^{*}$. The dashed lines correspond to $\pm \sigma$ values, assuming a 5-mm standard deviation for the displacement measurement and exact interpolated water levels (modified from Hoffmann et al. 2001)
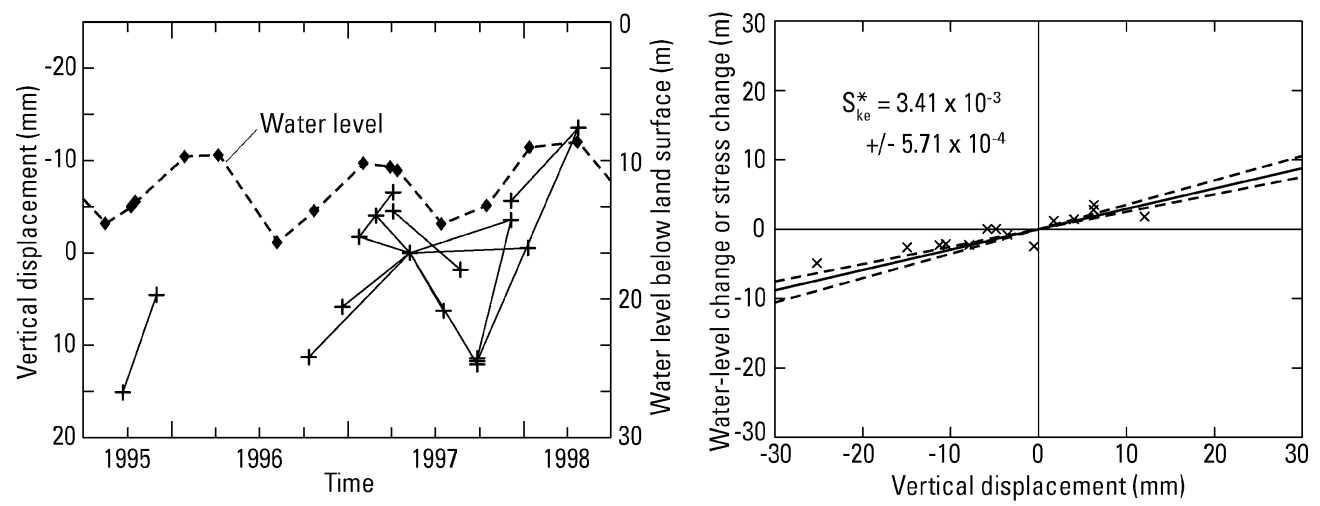

Lorenzi Extensometer
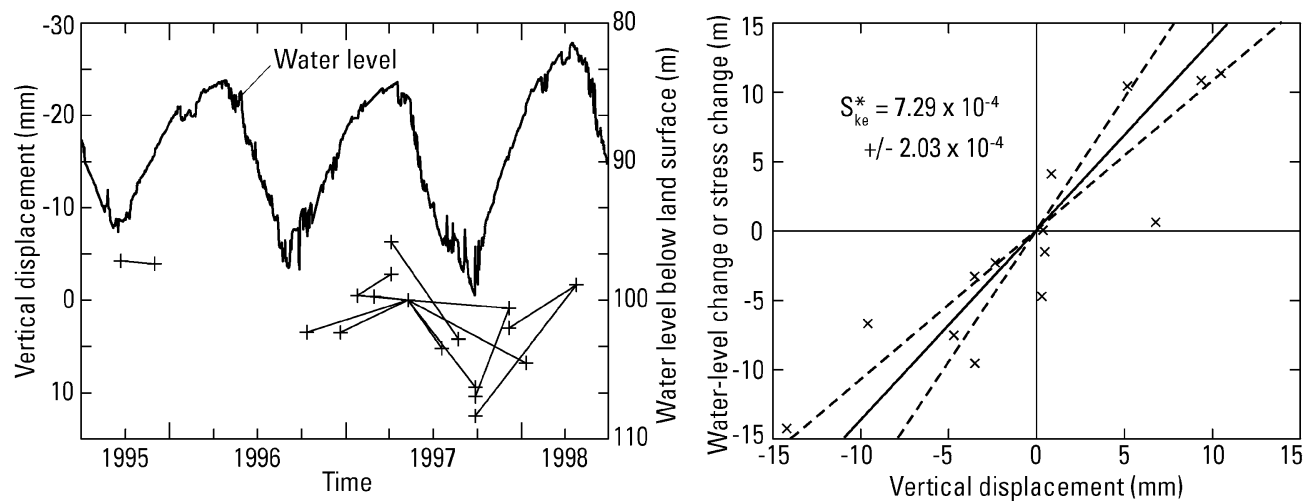
Fig. 8 Contours (thick black lines) of historical subsidence (1934-1967) in meters, Santa Clara Valley, California (modified from Poland and Ireland 1988). Benchmark locations are shown for two leveling lines (dots from $A$ to $A^{\prime}$, and $B$ to $B^{\prime}$ ); two borehole locations are shown (open squares); faults are shown as thin solid black lines, dashed where inferred (modified from Schmidt and Bürgmann 2003)

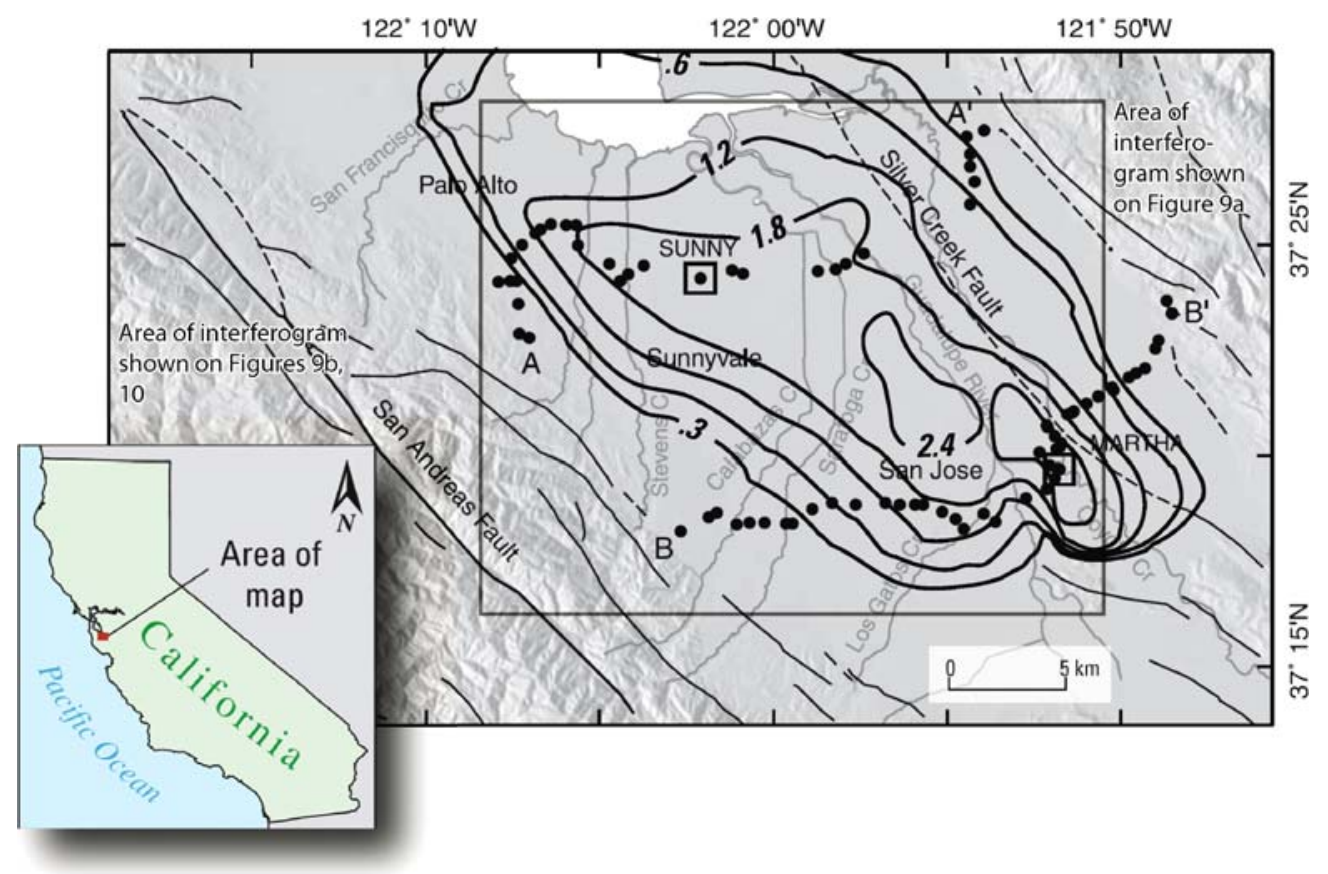

trace of an inferred northwesterly extension of the Silver Creek fault zone (Fig. 9; Ikehara et al. 1998). Steep displacement gradients were as high as $2 \times 10^{-5}(30 \mathrm{~cm}$ in $1.5 \mathrm{~km}$ ) at or near this boundary (Galloway et al. 2000a). Seismic imaging and geophysical investigations undertaken as a result of the interferograms confirmed the presence of a buried fault at this boundary (Catchings et al. 2000; Jachens et al. 2002; Williams et al. 2002). The linear shape of the displacement surface near this boundary suggests that, (1) the fault zone juxtaposes sedimentary sections of contrasting time-consolidation characteristics (stress history, compressibility, sediment thickness, and vertical hydraulic conductivity); and (or) (2) lateral groundwater flow across the fault zone is impeded (Galloway et al. 2000a).

A regional groundwater/surface-water flow model of the Santa Clara Valley subbasin was developed as a tool for resource managers seeking to minimize permanent land subsidence while maximizing water supply (Hanson et al. 2004). Historical hydrologic and subsidence data were used to constrain model calibration. Based on InSAR and recent geophysical information, the model simulates the Silver Creek fault as a partial barrier to groundwater flow.

\section{Yucca Flat, Nevada Test Site, Nevada}

Ground-surface deformation caused by tests of nuclear devices detonated underground at the Nevada Test Site (NTS) from 1951 to 1992 was evaluated using InSAR. Although U.S. nuclear testing was suspended in September 1992 when a moratorium on U.S. nuclear testing went into effect, 5 tests at Yucca Flat (YF) and Pahute Mesa (PM) postdate the first archived SAR data available from the European Space Agency ERS1 satellite. Numerous types of coseismic and postseismic ground-displacements were detected by InSAR at YF and PM including cratering, faulting, and persistent, sub-regional scale subsidence. Time series interferograms (1992-1997) revealed that the postseismic signals develop and persist for years. Spatially varying subsidence rates were attributed to variations in local geology, hydrogeologic characteristics, and deformation processes (Laczniak et al. 2003; Vincent et al. 2003). The patterns and rates of ongoing deformation led investigators to conclude that while the principal source of deformation at PM is gravity-driven closure of subsurface cracks formed in the spall zone above the test hypocenters, the principal deformation at YF is a poroelastic response.

During testing, poroelastic deformation at YF presumably caused some land-surface uplift attributed to the expansion of a low permeability tuff confining unit (the "tuff pile") overpressured by the energy of nuclear tests detonated below the water table in the tuff pile. When testing ceased in 1992, deformation was predominately manifest as surface subsidence (Fig. 11a,b) attributed to the recompression of the tuff pile accompanying delayed pore-fluid depressurization and drainage from the host tuffs into an overlying water table and an underlying regional carbonate aquifer (Laczniak et al. 2003; Halford et al. 2005). Although no known uplift associated with the pre-1992 period has been reported, this interpretation is supported by

1. The spatial extent of the InSAR-derived subsidence (Fig. 11a,b) which:

- Forms elliptical subsidence bowls as deep as $140 \mathrm{~mm}$ during a 5-year period (1992-1997) around epicenters of tests detonated below the water table

- Is truncated to the west and east by the Topgallant and Yucca faults, respectively, which bound the tuff pile 


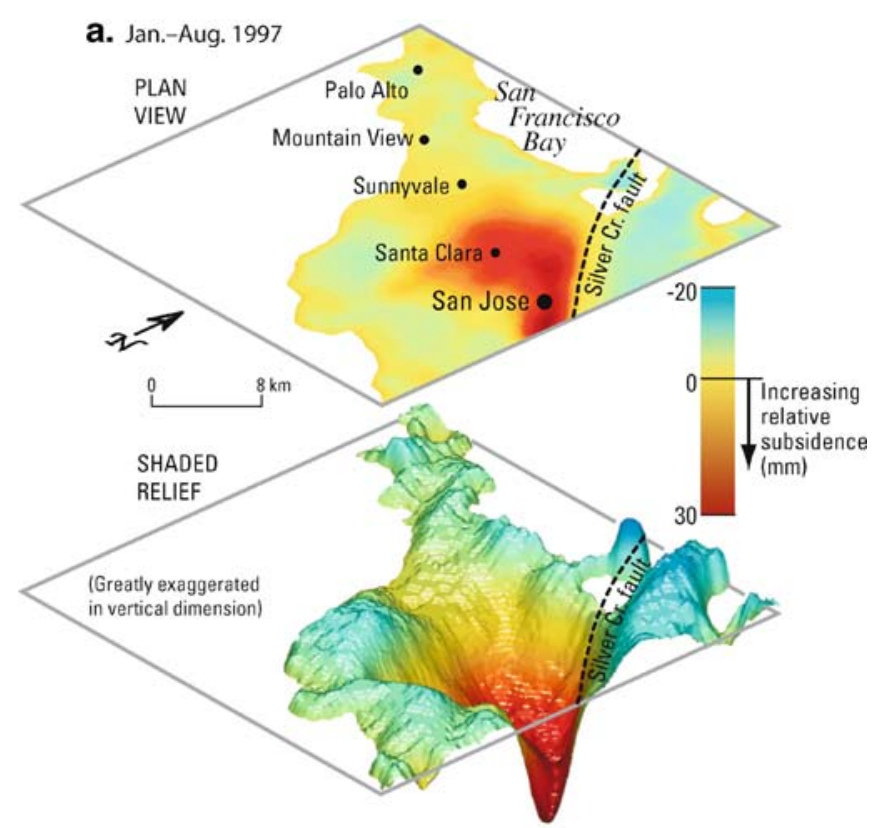

b. Aug. 1998-Mar. 1999

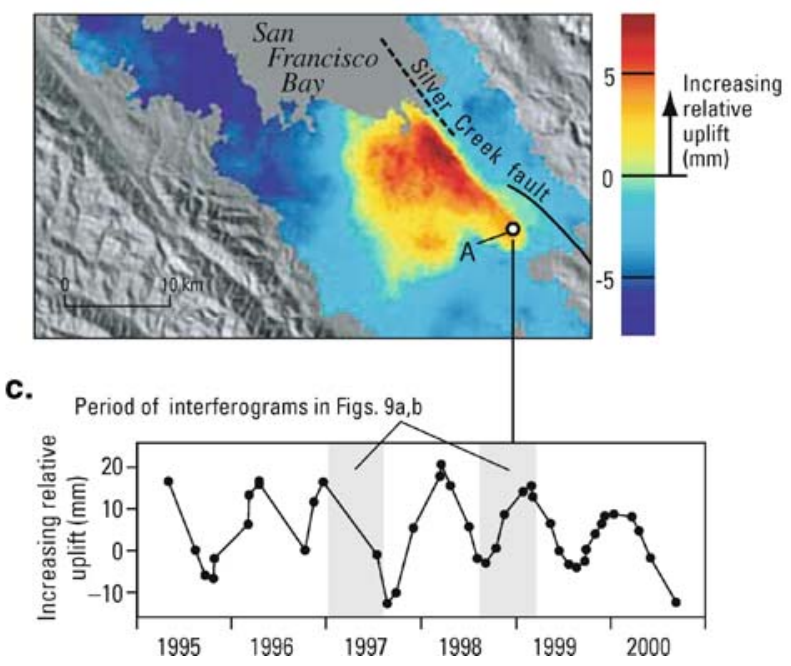

Fig. 9 InSAR-derived seasonal, relative subsidence and uplift, Santa Clara Valley, California, bounded on the northeast by Silver Creek fault: a seasonal subsidence (modified from Galloway et al. 2000b); b seasonal uplift (modified from Schmidt and Bürgmann 2003); c time series (1995-2000) at point A (b) (modified from Schmidt and Bürgmann 2003). Bounding areas for interferograms shown on Fig. 8. Different reference (zero motion) points were used to compute relative motions on $\mathbf{a}$ and $\mathbf{b}$

2. Measured water levels in wells completed in the tuff pile (Fig. 11c) which:

- Before testing ceased in 1992, increased more than $400 \mathrm{~m}$ in one well (UE-4t 1) above pretesting static levels

- After testing, decreased by nearly $75 \mathrm{~m}$ from 1992 to 2004, corresponding with the decreasing rate of subsidence (Fig. 11b)

- Typically take months to years to reach equilibrium after drilling (Fig. 11c) a. Sept. 1992-Oct. 1999

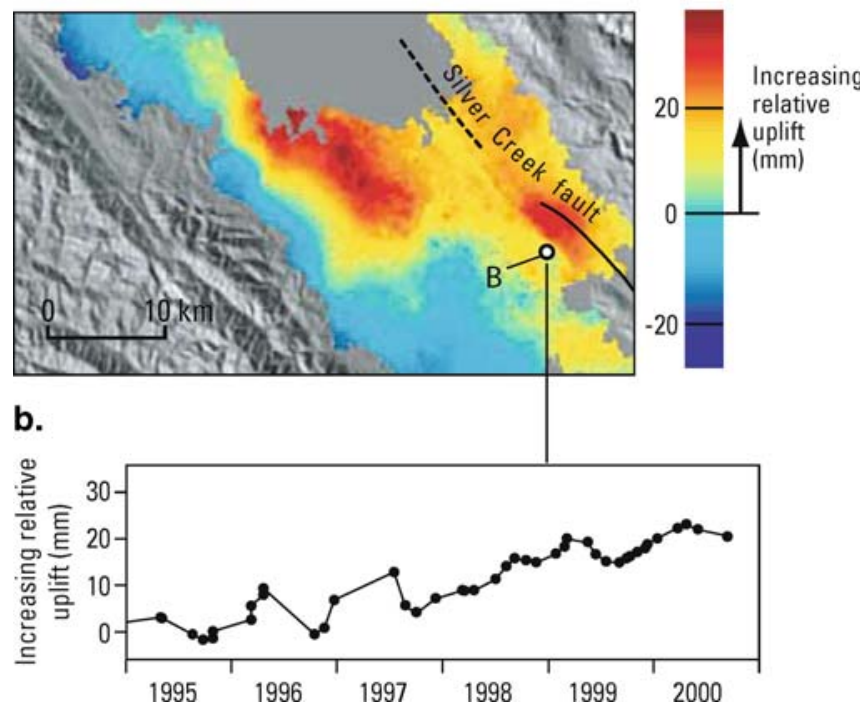

Fig. 10 InSAR-derived multi-annual, relative uplift, Santa Clara Valley, California: a possibly partitioned by Silver Creek fault; b time series (1995-2000) at point B (a) (modified from Schmidt and Bürgmann 2003)

3. Measured water levels in a well penetrating a testgenerated cavity (Fig. 11c) which showed a 45-m increase from 1992 to 1998, indicative of fluid-infilling

The observed InSAR displacements and water levels were used to constrain simulations of groundwater flow accompanying depressurization and poroelastic deformation in the tuff pile (Halford et al. 2005). Changes in groundwater flow and elastic ground displacements in the tuff pile (1962-2003) in response to nuclear tests detonated below the water table were simulated using a cross-sectional and a three-dimensional model (Figs. 11a, 12). Good agreement was achieved between simulated and observed subsidence rates (Fig. 13). Inverse simulations were used to constrain estimates of hydraulic conductivity and specific storage of the tuff pile, and the flux of groundwater to the underlying regional carbonate aquifer. The models were calibrated to measured water levels (1991-2003) and to InSAR-derived subsidence rates (1992-1997). The tuff pile was simulated as a homogeneous, isotropic unit characterized by a single hydraulic conductivity and specific storage. The Topgallant and Yucca faults were simulated as general-head boundaries with a small conductance of $3 \times 10^{-8} \mathrm{~m}^{2} / \mathrm{d}$ which impeded groundwater movement across the faults. Compression in the tuff pile was simulated as a poroelastic process that could be represented by:

$\Delta b=\frac{\Delta S}{S_{\mathrm{s}}}$

where

$\Delta b$ is the change in thickness, equated to change in ground-surface altitude (L), $\Delta S$ is the change in storage- 
a.

April 24, 1992-June 18, 1993
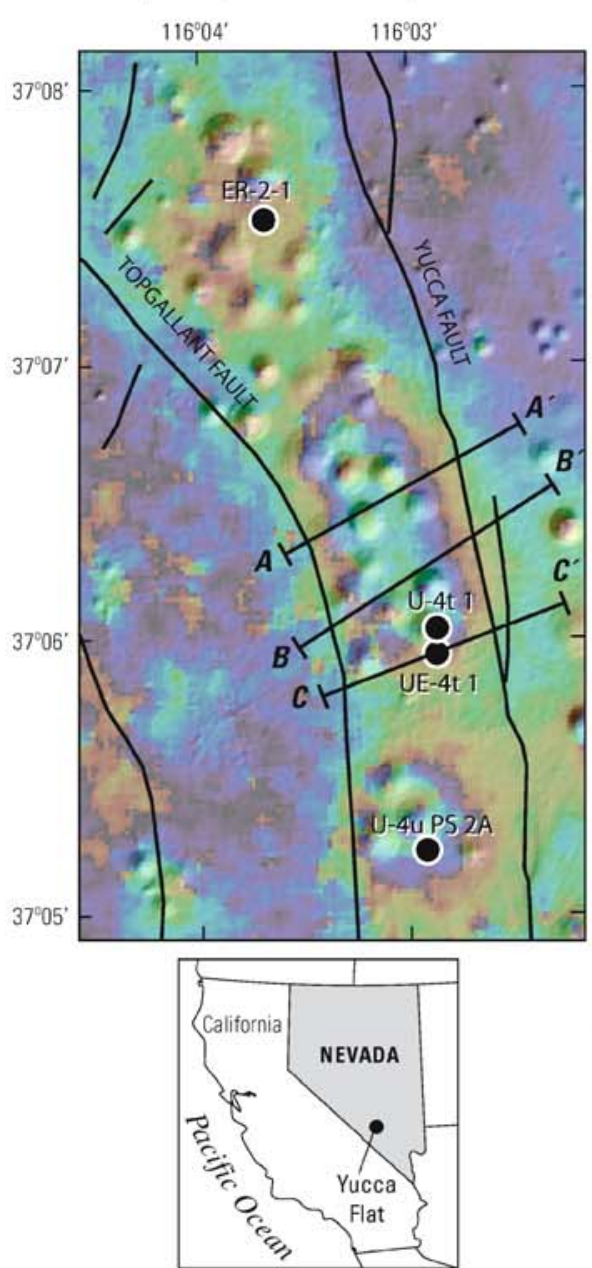

b.
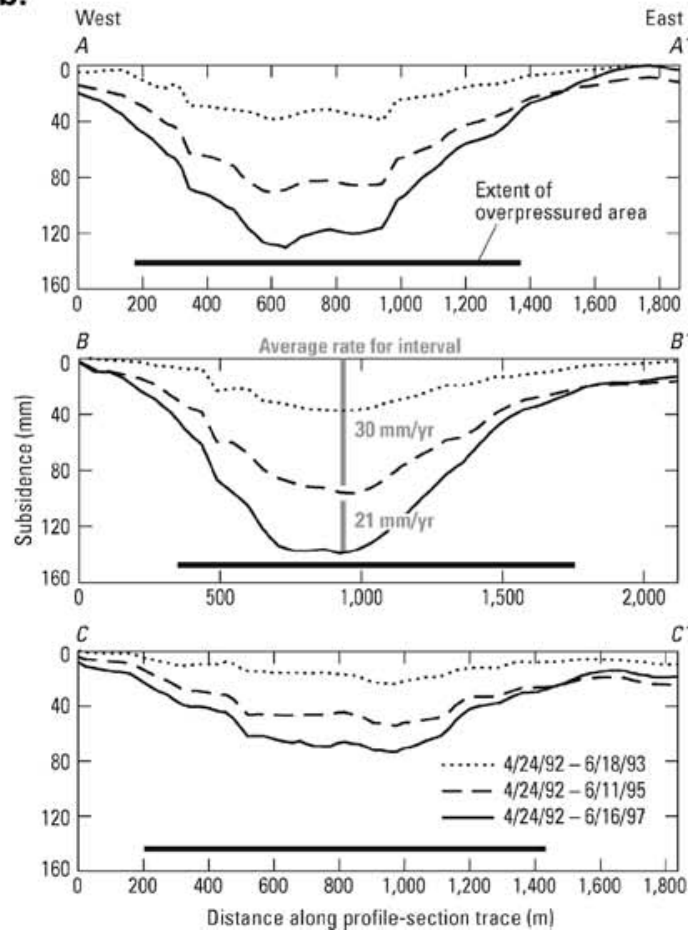

June 18, 1993-June 11, 1995
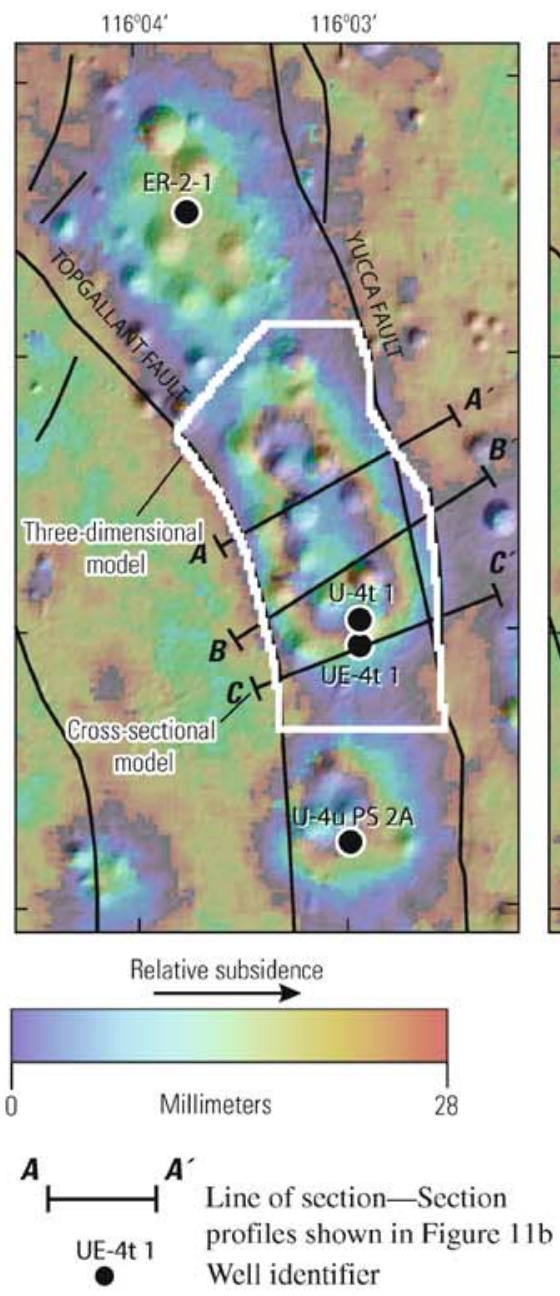

c.

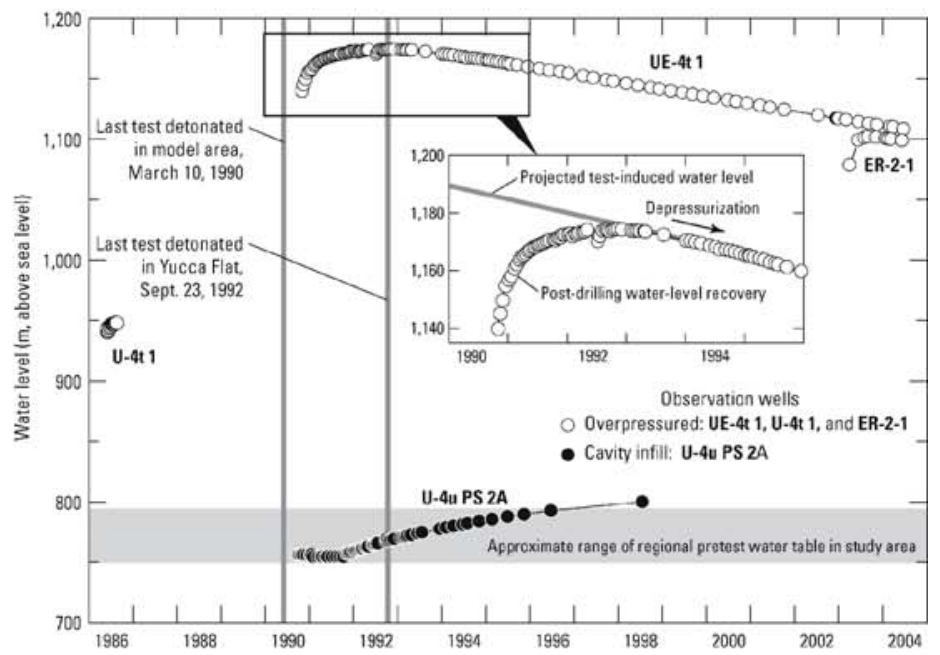

June 11, 1995-June 16, 1997
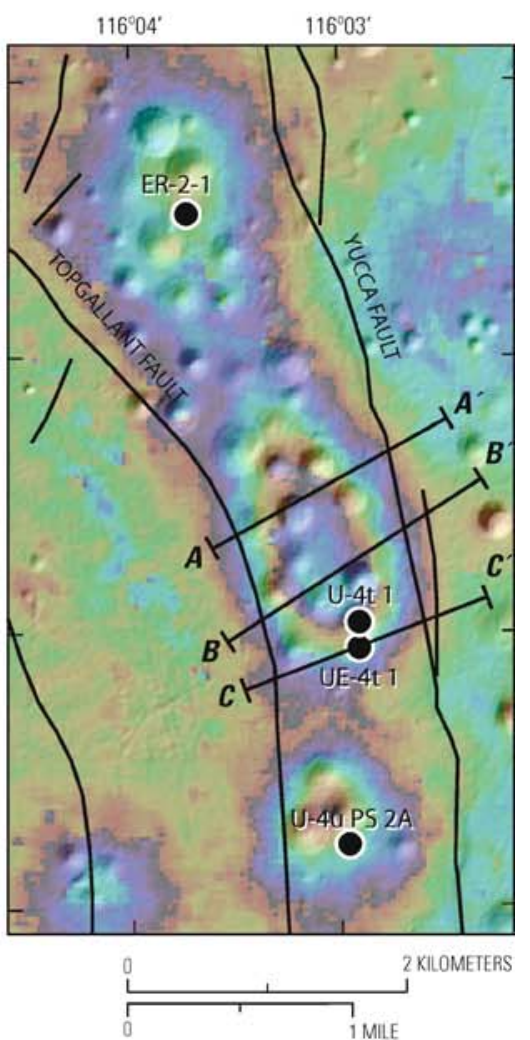

$\stackrel{N}{1}$ 
4Fig. 11 a InSAR observations within the overpressured area, central Yucca Flat, Nevada: InSAR-derived subsidence for three sequential time periods (24 April 1992-18 June 1993, 18 June 1993-11 June 1995, 11 June 1995-16 June 1997). b InSAR observations within the overpressured area, central Yucca Flat, Nevada: Cumulative regional-range displacement of ground surface along three profiles, derived by summing displacement values interpolated from three time-sequential interferograms (a), 24 April 1992-16 June 1997. c Groundwater levels within the overpressured area, central Yucca Flat, Nevada, measured during and after period of underground nuclear testing in bedded tuffs (modified from Halford et al. 2005)

the volume of water released from or taken into storage per unit area per unit change in head $\left(\mathrm{L}^{3} / \mathrm{L}^{3}\right)$ - and $S_{\mathrm{s}}$ is the specific storage - the volume of water released from or taken into storage per unit area per unit change in head per unit thickness $\left(\mathrm{L}^{-1}\right)$.

Specific storages of $6 \times 10^{-6}$ and $9 \times 10^{-6} \mathrm{~m}^{-1}$ were estimated using the cross-sectional and three-dimensional models, respectively. A hydraulic conductivity of $3 \times$ $10^{-6} \mathrm{~m} / \mathrm{d}$ was estimated by both models.

\section{Improved conceptual-model and parameter constraints for aquifer systems}

The case studies demonstrate how InSAR has been applied to mapping, monitoring, analysis, and simulation of deforming aquifer systems in compressible unconsolidated basin-fill and other alluvial and lacustrine deposits. The qualitative insights and quantitative parameter estimates derived from the spatial and temporal InSARderived displacement data, especially when used in conjunction with other hydrogeologic information are very useful in constraining regional hydrogeologic conceptual and numerical models of groundwater flow and aquifer-system compaction. The principal kinds of conceptual-model and parameter constraints provided by InSAR are discussed below.

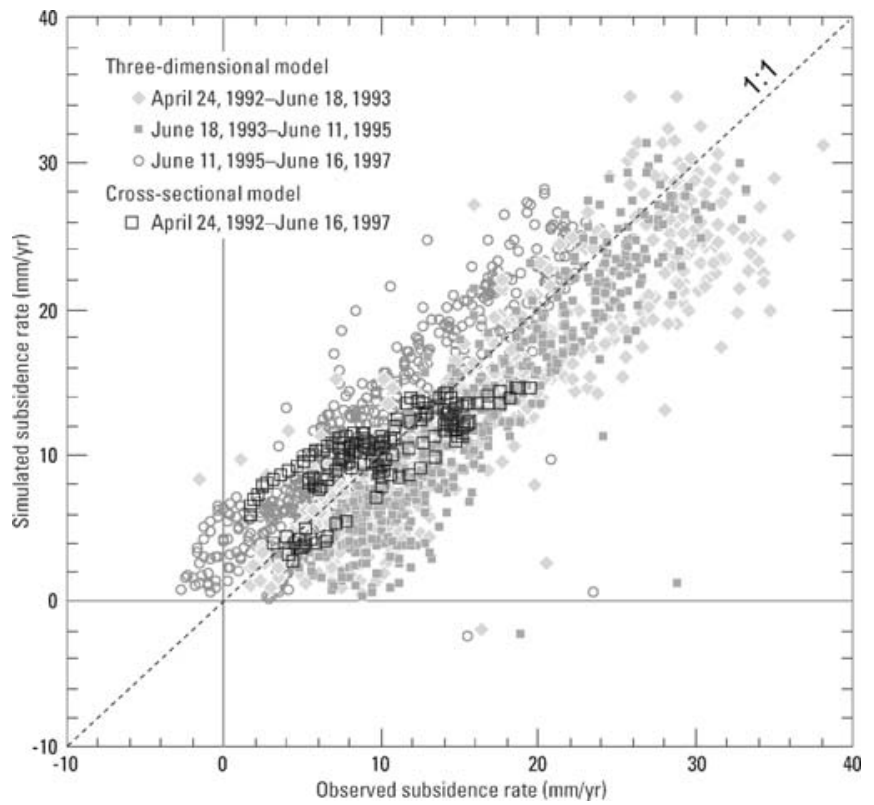

Fig. 13 Comparison of InSAR-derived subsidence rates and subsidence rates simulated with cross-sectional and three-dimensional models for different time periods between 24 April 1992, and 16 June 1997 for the overpressured area, central Yucca Flat, Nevada (modified from Halford et al. 2005)

Faults as barriers to groundwater flow

Faults can be important hydraulic components in regional groundwater flow systems. Faults affecting groundwater flow in saturated unconsolidated basin-fill deposits typically are barriers to flow. Where sufficient water-level information is available, large horizontal hydraulic gradients generally identified from regional potentiometric surface maps are used to infer the presence of buried faults or substantiate the effect of mapped faults on groundwater flow (e.g. Dutcher and Garrett 1963). The boundaries of groundwater basins and subbasins frequently are defined on the basis of faults. Faults impeding flow may juxtapose hydrogeologic units of contrasting horizontal hydraulic conductivity, contain low-permeability fault gouge, and
Fig. 12 Time line showing periods of InSAR-derived subsidence and water-level observations with magnitude of water-level change used to calibrate cross-sectional and three-dimensional models, and detonations used to develop a three-dimensional model for the overpressured area, central Yucca Flat, Nevada (modified from Halford et al. 2005)

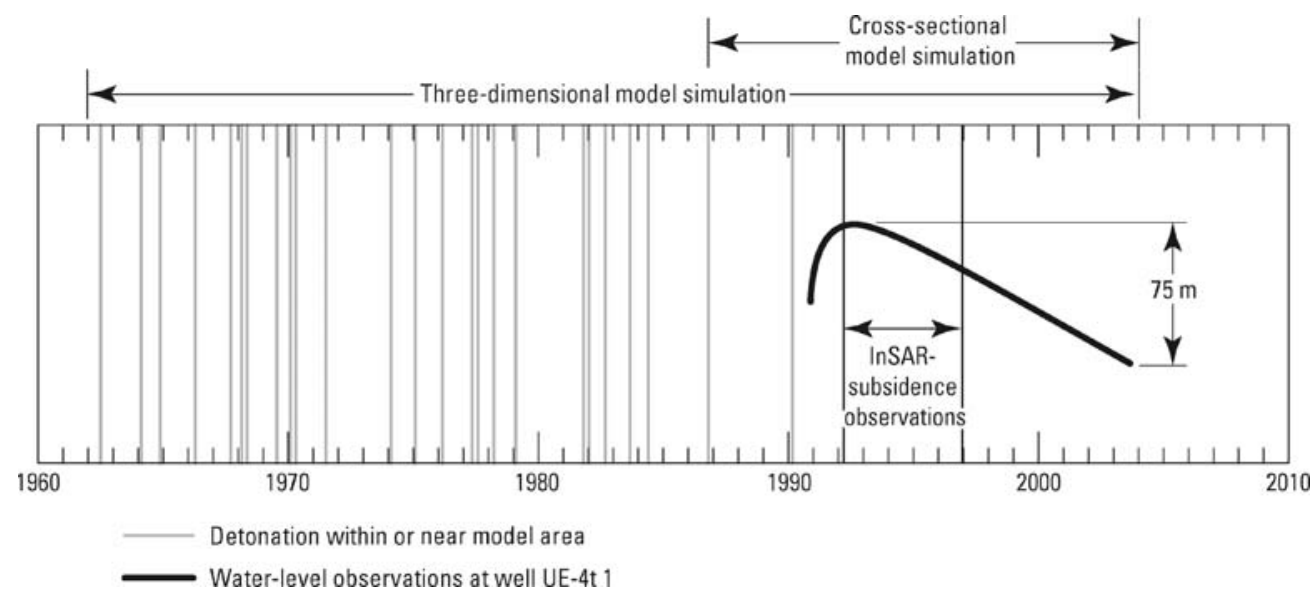


(or) drag, smear, and compress interbedded aquitards into steeply dipping barriers to flow, resulting in elevated heads (water levels) upgradient from the fault and very steep hydraulic gradients through the fault zone.

One of the more important results derived from the spatially-detailed InSAR displacement maps is the identification of discrete differential ground displacements associated with the presence of mapped and unmapped faults. The effectiveness of InSAR in identifying potential fault locations depends upon the skeletal compressibilities and temporal water-level changes in laterally adjacent hydrogeologic units that may be separated by the fault. Steep displacement gradients across typically linear alignments on the displacement maps can indicate potential fault barriers, and these features are favored by relatively large skeletal compressibilities and water-level changes for the hydrogeologic units on at least one side of the fault. In the presence of relatively large water-level changes abrupt spatial contrasts in sediment facies caused by depositional factors or by subsequent erosion or alteration also can cause steep displacement gradients. Frequently, the lateral transition of sediment facies is gradual and so are the displacements associated with their deformation.

Several of the case studies presented above show how the InSAR displacement maps contributed to new information about the roles of specific faults in their groundwater flow systems. Many other studies have demonstrated the use of InSAR in identifying the influence of geologic structure on deformation attributed to groundwater discharge and recharge (e.g. Bawden et al. 2001; Lu and Danskin 2001; Heywood et al. 2002; Buckley et al. 2003).

In Santa Clara Valley, a buried extension of the Silver Creek fault (zone) was first identified on InSAR (Figs. 8, 9 and 10) and subsequently confirmed using focused geophysical surveys. One interesting aspect of the Silver Creek fault is that differential displacements are primarily evident on seasonal time scales. Another is that the effect of the fault is evident even though the system was in the elastic range of deformation and therefore governed by the elastic skeletal components of specific storage (compressibilities) which typically are more than an order of magnitude smaller than inelastic skeletal specific storages (Riley 1998).

In Las Vegas Valley, the surface trace of the previously mapped Eglington fault was correlated to the InSARmapped boundary of the northwest subsidence bowl (Figs. 3, 4). Though local differential displacements, antithetical to past motion on the fault, had been measured (Bell and Price 1991), their relation to the regional displacement field was unknown prior to the availability of InSAR (Bell et al. 2002). InSAR-mapped displacements were correlated to other known faults especially along the southwest boundary of the southern subsidence bowl, and those separating the North Las Vegas subsidence bowl from the central subsidence bowl (Figs. 3, 4).

In Yucca Flat, the western and eastern boundaries of the InSAR-mapped displacements were correlated to the traces of the mapped Topgallant and Yucca faults (Fig. 11a). These patterns combined with water levels and other hydrogeologic information led investigators to represent the faults as general-head boundaries with small conductances that impede lateral flow in simulations of flow in the intervening tuff pile (Halford et al. 2005).

\section{Distribution of compressible sediments}

When used in conjunction with water-level and hydrostratigraphic information, the spatially-detailed InSARmapped displacements can aid in mapping compressible sediments and identifying areas that may be overconsolidated. InSAR-observed displacements attributable to aquifer-system deformation occur where sediments with sufficiently large compressibilities (usually unconsolidated silts and clays) are present and are subject to sufficiently large stresses (water-level variations), typically caused by groundwater discharge (e.g. pumping) and (or) recharge. The absence of observed displacements in areas subject to relatively large stresses suggests that highly compressible deposits may be absent or, where present, may be overconsolidated. This information is useful in reconstructing the sedimentary and possibly the climatic history of a basin, and in constraining basin hydrogeologicframework and numerical flow and subsidence models (Hanson et al. 2004).

In Las Vegas Valley, Nevada, the InSAR-mapped subsidence from 1992 to 1997 was correlated to the intersection of the distributions of aggregate clay thickness (Fig. 5c) and water-level decline from predevelopment to 1990 (Fig. 5a; Amelung et al. 1999). The subsidence areas were offset east of the areas of maximum water-level change, and west of the areas of maximum aggregate clay thickness. The absence of any significant subsidence in the area of maximum water-level decline was attributed to the lack of significant clay thickness and to the attainment of the minimum water level some 22 years before the InSAR observations. Historically (1963-2000), generally less than $0.3 \mathrm{~m}$ of subsidence has been measured (Bell et al. 2002) in this area of maximum water-level decline (Fig. 3b).

One possible explanation for the absence of significant InSAR-derived displacements south of Lancaster in Antelope Valley, California (Fig. 1a), despite the known presence of fine-grained sediments (lacustrine) and large groundwater level declines, is the overconsolidation of those deposits (Galloway et al. 1998). There were significant differences in this region between InSARmapped subsidence (negligible) and the model-simulated subsidence for the period of the interferogram $(30 \mathrm{~mm})$. This is not surprising because the aquifer-system compaction model was based on the available hydrogeologic and historical terrestrial geodetic information, not on the InSAR observations. Subsequently, based in part on the InSAR observations, paleomagnetic analyses of cores collected in 1998 during drilling of a monitor well located south of Lancaster near the Lancaster extensometer site 
(Fig. 1a) indicated that the lacustrine units in this part of Antelope Valley were older than about 780,000 years (Fram et al. 2002). Consolidation tests on select cores indicated the lacustrine deposits were consolidated (Peter Martin, US Geological Survey, unpublished data, 2006). In contrast, the lacustrine units northeast of Lancaster near Rogers Lake are probably less than 14,000 years old (Ponti 1985), underconsolidated and more compressible (Sneed and Galloway 2000) than those at the Lancaster extensometer site (Phillips et al. 2003). Subsequent models have simulated subsidence using smaller compressibilities and larger preconsolidation stresses in the region south of Lancaster based on the InSAR observations and the core analyses (Hoffmann et al. 2003a; Leighton and Phillips 2003), and have achieved good agreement with the observations.

\section{Storage estimates}

Precise, continuous measurements of compaction from borehole extensometers, combined with time-series waterlevel measurements from nearby piezometers have been used to define stress-strain relations and compute storage coefficients of deforming aquifer systems (e.g. Riley 1969; Hanson 1989; Pavelko 2000, 2004; Sneed and Galloway 2000). Terzaghi's (1925) principle of effective stress has been used to relate variations of groundwater level (hydraulic-head) and effective stress on the skeleton of a saturated porous medium:

$\Delta \sigma_{\mathrm{e}}=\sigma_{\mathrm{T}}-\gamma \Delta h$,

where $\sigma_{\mathrm{e}}$ is the effective or intergranular stress $\left(\mathrm{ML}^{-1} \mathrm{~T}^{-2}\right)$, $\sigma_{\mathrm{T}}$ is the total stress $\left(\mathrm{ML}^{-1} \mathrm{~T}^{-2}\right), \gamma$ is the specific weight of water $\left(\mathrm{ML}^{-2} \mathrm{~T}^{-2}\right)$, and $h$ is hydraulic head $(\mathrm{L})$.

The aquifer-system storage coefficient is dimensionless and under confined conditions

$S^{*}=S_{\mathrm{k}}^{*}+S_{\mathrm{w}}$,

where $S_{\mathrm{w}}$ is the storage owing to the compressibility of the pore water in the aquifer system, and $S_{k}^{*}$ is the aquifersystem skeletal storage

$S_{\mathrm{k}}^{*}=S_{\mathrm{sk}}^{*} b^{*}=\alpha_{\mathrm{k}}^{*} \gamma b^{*}$

where $S_{\mathrm{sk}}^{*}$ is the skeletal specific storage, $\alpha_{\mathrm{k}}^{*}$ is the skeletal compressibility $\left(\mathrm{M}^{-1} \mathrm{LT}^{2}\right)$, and $b^{*}$ is the thickness of the aquifer system (* denotes aquifer-system properties).

Basin-fill alluvial aquifer systems typically are heterogeneous and comprise sedimentary deposits of variable grain sizes, porosities, hydraulic conductivities and thicknesses. The deposits are grouped into two types of hydrostratigraphic units, aquifers and aquitards. $S_{k}^{*}$ is the bulk skeletal storage comprising the skeletal storages of the aquifers and aquitards. In unconsolidated alluvial aquifer systems of specific thickness, typically $S_{k}^{*}>S_{\mathrm{w}}$ and the change in storage caused by a change in head is largely determined by the skeletal compressibility. Two aquifer-system skeletal storages, $S_{\mathrm{kc}}^{*}$ and $S_{\mathrm{kv}}^{*}$, specific storages, $S_{\mathrm{ske}}^{*}$ and $S_{\mathrm{skv}}^{*}$, and compressibilities, $\alpha_{\mathrm{ke}}^{*}$ and $\alpha_{\mathrm{kv}}^{*}$, can be defined for the elastic and inelastic ranges of stress, respectively. Generally, hydrogeologists have assumed that the coarse-grained sediments in aquifer systems deform elastically, and the fined-grained sediments that constitute the confining and interbedded aquitards may deform both elastically and inelastically. The storage coefficient commonly used in the confined groundwater flow equation and evaluated in aquifer hydraulic tests is the elastic storage

$S \approx S_{\mathrm{ke}}+S_{\mathrm{w}}$

where the aquifer elastic skeletal storage is

$S_{\mathrm{ke}}=S_{\mathrm{ske}} b=\alpha_{\mathrm{ke}} \gamma b$

where $b$ is aquifer thickness, or in an aquifer hydraulic test, the thickness of the stressed portion of the aquifer. Riley (1969) showed that for periods of slowly changing effective stress and constant total stress (Eq. 3) $S_{\text {ke }}$ could be calculated from paired time-series of head change and displacements by

$S_{\mathrm{ke}}=\frac{\Delta b}{\Delta h}$,

where, for the elastic range of stress, $\alpha_{\mathrm{ke}}=(|\Delta h| \gamma)^{-1}$.

Elastic storage coefficients for Las Vegas Valley were computed (Eq. 8) using time-series displacements $(\Delta b)$ measured from interferograms of Las Vegas Valley combined with paired water-level time series $(\Delta h$; see Las Vegas Valley case study; Hoffmann et al. 2001; Fig. 7). The seasonal InSAR-derived displacement maps of Las Vegas Valley, in conjunction with groundwater levels, yielded spatially varying estimates of storage coefficients for those parts of the aquifer system undergoing largely elastic deformation. For a site in the Santa Clara Valley, measured water-level time-series transformed (Eq. 8) into displacements using $S_{\mathrm{ke}}$ previously determined from piezo-extensometric analysis (Poland and Ireland 1988) compared favorably to contemporaneous InSAR-derived time-series displacements (Fig. 14; Schmidt and Bürgmann 2003).

\section{Aquitard drainage: delayed, persistent deformation}

In many confined and semiconfined alluvial aquifer systems aquitards (low-permeability layers of silt and clay) constitute the major portion of the intermediate and long-term groundwater storage capacity of the system, even under conditions of essentially elastic deformation. This is by virtue of their substantially greater porosity and compressibility and typically their greater aggregate thickness compared to the more permeable coarse-grained 


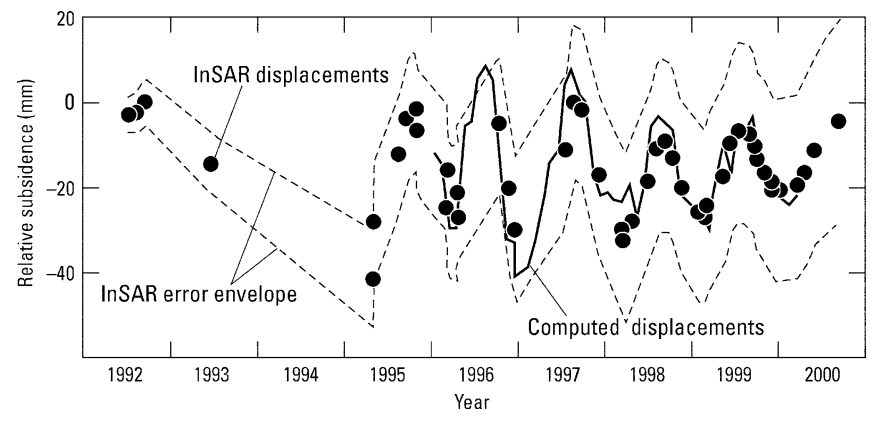

Fig. 14 Computed displacements based on monthly measured water levels and elastic skeletal storage coefficient $\left(S_{\mathrm{ke}}\right)$ compared to InSAR-derived time-series displacements for a well near the MARTHA site (shown on Fig. 8), Santa Clara Valley, California (modified from Schmidt and Bürgmann 2003)

aquifers. For a large area in the San Joaquin Valley (California), 150-200 km southeast of the Santa Clara Valley, Poland et al. (1975) estimated that about $1 / 3$ of the approximately 37 billion $\mathrm{m}^{3}$ of groundwater extracted during 1930-1970 was derived from 'water of compaction'-water released from storage through inelastic compaction of the aquitards, under anthropogenic stress that greatly exceeded the threshold of maximum past natural stress (the preconsolidation stress). During this period, more than $8 \mathrm{~m}$ of subsidence occurred locally.

Because of the low permeability and relatively large inelastic storage of aquitards and thick interbeds, the drainage of these units may lag far behind the lowering of water levels in adjacent aquifers. Generally, when heads in adjacent aquifers are changing, the equilibration of heads in the aquitards is lagged, and much more so for decreasing heads in the inelastic range of stress. The lagged responses in the inner portions of thick, interbedded aquitards and the distal portions of thick, confining units are relatively isolated from the higher frequency seasonal head fluctuations in the aquifers and more responsive to the lower frequency, annual and longer-term trends in aquifer head. The migration of effective-stress changes in the aquitards accompanies the approach to equilibration of heads throughout the aquifer system and results in delayed deformation of the system. The accompanying land subsidence owing to compaction of the slowest draining aquitards may persist for decades to centuries.

Perhaps the most important form of persistent deformation in aquifer systems is residual compaction. Residual compaction is the difference between (1) the amount of compaction that will occur ultimately for a given increase in applied stress, and (2) that which has occurred at a specified time. Terzaghi's (1925) theory of hydrodynamic consolidation describes the delay in draining aquitards when heads are lowered in adjacent aquifers, as well as the residual compaction that may continue long after drawdowns in adjacent aquifers have stabilized. Based on this theory, Riley (1969) noted that a time constant $\tau$ (T) for a doubly draining aquitard following an instantaneous step decrease in head in the adjacent aquifers may be defined as

$\tau \approx \frac{S_{\mathrm{s}}^{\prime}\left(\frac{b^{\prime}}{2}\right)^{2}}{K_{\mathrm{z}}^{\prime}}$,

where the prime (') denotes aquitard properties, $K_{\mathrm{z}}^{\prime}$ is the vertical hydraulic conductivity, and $S_{\mathrm{s}}^{\prime}$ is the specific storage (for stresses larger than the preconsolidation stress, $S_{\mathrm{skv}}^{\prime} \approx S_{\mathrm{s}}^{\prime}$ and may be substituted in Eq. (9). The time constant $(\tau)$ is the time required to attain about $92 \%$ of the ultimate compaction following a step decrease in head in the adjacent aquifers. Riley (1969) determined values of $S_{\text {skv }}^{\prime}$ from stress-strain analysis of seasonal episodes of inelastic compaction measured at an extensometer in the San Joaquin Valley, California. He computed that the variable summer irrigation pumping in nine consecutive years produced only $4.6-8.3 \%$ of the ultimate compaction potentially attributable to the seasonal drawdowns observed in the aquifers. These values defined an average inelastic time constant of 4.6 years, from which he calculated an average vertical hydraulic conductivity, using Eq. (9). Thus, deformation data, coupled with measured stress change, was shown to be capable of yielding estimates of aquitard hydraulic conductivity, as well as compressibility. Others have used these concepts to constrain estimates of $S_{\mathrm{skv}}^{\prime}$ in aquifer-system compaction models (e.g. Helm 1975, 1978; Epstein 1987; Hanson 1989; Sneed and Galloway 2000; Hoffmann et al. 2003a; Pavelko 2004). From these analyses, time constants from 1 to more than 1,000 years have been computed.

InSAR is very useful for identifying areas affected by residual compaction when concurrent groundwater level information is available. Because groundwater levels measured in wells tend to represent heads in aquifers in which the wells are screened preferentially, ongoing subsidence while groundwater levels are stable or recovering likely indicates residual compaction is occurring. InSAR has been used to identify and map large areas in Antelope Valley and Las Vegas Valley where residual compaction occurs in response to historical groundwater pumping. Time-series piezo-extensometric data from borehole extensometer sites in each valley demonstrate residual compaction (Sneed and Galloway 2000; Pavelko 2000, 2004). Time constants computed on the basis of one-dimensional simulations of aquifer-system compaction constrained by borehole extensometer data ranged from 17 days to 350 years in Antelope Valley (Sneed and Galloway 2000) and from 100 to 1,300 years in Las Vegas Valley (Pavelko 2004). In Antelope Valley, InSAR combined with groundwater level information revealed that residual compaction is occurring south of Rogers Lake, roughly correlating with the distribution of a mapped lacustrine unit (Hoffmann et al. 2003a). In Las Vegas Valley, residual compaction is occurring over much of a subsidence-affected area south of the Eglington fault in areas of large aggregate clay thickness where water levels in aquifers have generally recovered since 1990, and where the InSAR-derived 
displacements (1992-1997) show significant subsidence (Amelung et al. 1999; Fig. 5b).

InSAR-derived displacements and other hydrogeologic information were used to constrain an inverse model of coupled groundwater flow, delayed aquifer-system compaction and land subsidence for the Antelope Valley (see Antelope Valley case study; Hoffmann et al. 2003a). Computed aquitard time constants ranged from 3.8 to 285 years. Although accounting for delayed compaction significantly improved agreement between the simulated subsidence and the observations, the temporal coverage (3 years) of the SAR data did not closely constrain the larger time constants.

Persistent deformation attributed to aquitard drainage but unrelated to groundwater pumping occurs in Yucca Flat, Nevada (see Yucca Flat case study). InSAR revealed persistent subsidence over an aquitard (tuff pile) 5 years after the cessation of underground nuclear weapons testing below the water table in this unit (Laczniak et al. 2003; Vincent et al. 2003; Fig. 11). In 1992, when testing stopped, water levels in the tuff pile, initially elevated nearly $400 \mathrm{~m}$ above pretesting static water levels, began to decline toward their undisturbed values. The InSARderived subsidence during 1992-1997 is attributed to elastic compression of the tuff pile accompanying its slow drainage. Halford et al. (2005) simulated groundwater flow in the tuff pile to estimate hydraulic parameters governing the efflux of potentially contaminated groundwater into an underlying regional carbonate aquifer. Parameter estimates were constrained by measured water levels and InSAR-derived subsidence rates. Predictive simulations indicated that owing to the cumulative effects of nuclear testing, 2 million $\mathrm{m}^{3}$ of groundwater will ultimately discharge from the tuff pile to the carbonate aquifer, and $50 \%$ of the ultimate discharge and subsidence attributed to the effects of nuclear tests to date would occur by 2005 , and $92 \%$ by 2200 .

\section{Limitations}

The chief utilities of satellite differential SAR interferometry in hydrogeologic studies are the spatially detailed maps and time-series measurements of aquifer-system deformation. Hydrogeologic processes unrelated to deformation of the aquifer system are not sensed, with the possible exception of some shallow processes related to changes in the dielectric constants of shallow soils (Nolan et al. 2003). For groundwater recharge, flow and discharge processes, the principal limitation of InSAR and PSI is that most consolidated-rock aquifer systems and the relatively thin, high-permeability coarse-grained deposits in basin-fill alluvial aquifer systems tend to deform least in response to hydro-mechanically coupled hydrogeologic stresses. Water-resources development focuses on these permeable, highly conductive coarse-grained fractions that readily yield water to wells. However, most alluvial aquifer systems are heterogeneous and comprise significant fractions of high-compressibility, high-storage, low- permeability, fine-grained silt- and clay-rich aquitards interbedded with and confining the coarse-grained aquifers. To date, most InSAR applications to deforming aquifer systems are limited to these types of systems.

Another important limitation is the rapid loss of coherence between SAR images over time for many types of terrain. InSAR loses coherence in areas that are heavily vegetated or where the ground surface is disturbed such as in agricultural areas. Although PSI side-steps this issue in urban areas, the problem is particularly limiting in rural and agricultural areas where PSI frequently fails to produce reliable results. Unfortunately, irrigated agriculture that is reliant on groundwater is a principal land use in many basins susceptible to aquifer-system compaction.

Atmospheric (moisture, pressure, temperature) effects are significant in many interferograms. Changes in atmospheric conditions cause temporal and spatial variations in the propagation of the transmitted and reflected radar waves, which are manifest as interferometric phase changes (Zebker et al. 1997) that can be difficult to discern from deformation. These atmospheric artifacts are prevalent in humid coastal regions (e.g. Stork and Sneed 2002; Buckley et al. 2003). The artifacts are possible anywhere and are not uncommon in arid regions, for example in the southwest USA during the summer monsoon season (Heywood et al. 2002), and in other arid basins leeward and adjacent to coastal mountain ranges such as in the Mojave Desert northeast of Los Angeles (Sneed et al. 2003).

Three main factors related to the satellite orbits and the SAR sensors commonly used for InSAR (ERS, Radarsat, J-ERS, and Envisat-ASAR) impose limitations on the application of InSAR to surface deformation monitoring:

1. Temporal decorrelation on vegetated terrain is often severe at C-band radar frequencies, used by the ERS, Radarsat and Envisat-ASAR sensors. As noted above, irrigated agriculture is the primary cause for groundwater overdraft and resulting aquifer-system compaction in many areas. Thus, decorrelation attributed to vegetation cover frequently prevents InSAR measurements over these aquifer systems.

2. For displacement mapping, SAR scenes would ideally be acquired from exact repeat orbits to eliminate effects of topography on the measured signal. Although topographic effects are corrected using a DEM during the processing, DEMs of adequate quality are not always available and residual effects may remain. Pairs of SAR scenes suitable for interferometric change detection can be selected to minimize topographic effects. As the existing sensors most commonly used in the past (ERS, Radarsat) were not designed to optimize interferometric processing, only a subset of the available SAR acquisitions is typically suitable for interferometric change detection. Future acquisitions frequently will not pair with any other SAR acquisitions of interest as the orbit tracks are not repeated with sufficient accuracy. Therefore, for InSAR one can expect to achieve a SAR-image sample frequency 
significantly less than the repeat-orbit cycle of these satellites (e.g. $\approx \frac{1}{35} d^{-1}$ for ERS and Envisat, and $\approx \frac{1}{24} d^{-1}$ for Radarsat).

3. SAR interferometry measures LOS range displacements. For example, the look angle $\alpha$ for the ERS $\left(20-26^{\circ}\right)$ and Envisat $\left(20-45^{\circ}\right)$ platforms is more sensitive to vertical than to horizontal displacements at least by a factor of $\frac{1}{\tan \alpha}$ (e.g. $\approx 2.4$ for $\alpha=23^{\circ}$ ). Using SAR pairs from ascending orbits and SAR pairs from descending orbits for roughly the same period, one can assess whether the opposed look angles reveal differences attributed to horizontal displacements (Hoffmann and Zebker 2003). However, generally, there are few available ascending acquisitions and it is difficult to resolve the horizontal displacement components without additional assumptions. Investigations focusing on horizontal surface displacements might use acquisitions at larger incidence angles to increase sensitivity. Nevertheless, additional information will generally be necessary to obtain a three-dimensional displacement field from interferometry using space-based sensors on polar orbits (Wright et al. 2004).

The global availability of SAR acquisitions is somewhat limited. Many areas have few or no acquisitions unless the area of interest previously was tasked for imaging. For example, there are subsiding areas in Mexico and in the People's Republic of China that have significant aquifer-system compaction problems with limited ERS SAR coverage. For Envisat SAR coverage, the various selectable polarizations of the transmitted electromagnetic SAR signal may limit the availability of SAR-image pairs suitable for InSAR processing.

ERS1 SAR acquisitions suitable for interferometry are available for the period 1992-1996, and ERS-2 data are available for the period 1995 to present, though ERS-2 data have been degraded since 2001 owing to navigation problems. Suitable interferometric pairs can be formed using combinations of ERS-1 and (or) ERS-2 SAR data for the period 1992-present. The Envisat satellite was launched in 2002 and is expected to operate through the launch of the SENTINEL-1 mission in 2011. Envisat and ERS data generally cannot be used to form interferometric pairs, though they may be combined in a PSI analysis. For change-detection in most hydrogeologic applications there are two significant gaps in the temporal availability of suitable SAR data: (1) 1995-1996, 9 months when ERS-1 and ERS-2 were flown in a tandem mission; and (2) 2001-2002, when ERS-2 data became degraded, prior to the availability of Envisat data.

Radarsat acquisitions, available since 1996, have not been exploited in hydrogeologic applications to the extent that the ERS data have. The primary reason for this is probably that the use of Radarsat data was not advertised for use in scientific investigations as much as ERS data. Other issues, though, are the less accurate orbit control of the satellite, causing additional complexities in meeting the geometric requirements for InSAR processing, the lack of a scientific background mission to build up a useful archive, and the variety of sensor acquisition modes, which reduces the chances of getting images that can be combined interferometrically. JERS-1 was an L-band sensor operating from 1992 to 1998. Although the L-band frequency is affected much less by decorrelation effects and hence probably more promising, the data have not been used as much as the ERS C-band data.

Other factors that tend to limit the wide-spread application of satellite-borne SAR interferometry to hydrogeologic studies include data processing, tasking the satellite imagery, and the scarcity of ground-truth information. Commercially available processing software is expensive and can involve a significant investment to develop the skills necessary to generate representative interferograms. Depending upon the location of one's study area, and the period of interest, the archive of available SAR imagery may be too small or nonexistent. Tasking the satellite to acquire new imagery may require principal-investigator status with the respective mission controllers, and further is dependent on other tasking priorities. These factors tend to limit the casual application of InSAR and discourage reconnaissance of deforming aquifer systems. Another limiting factor is the paucity of geodetic, and hydrogeologic ground-truth information to aid interpretation of the interferograms.

\section{Future applications}

Some of the ongoing applications of InSAR enhance definition of the spatial distribution of deformable aquitards in heterogeneous, alluvial aquifer systems and improve understanding of how these units interact with the aquifers. The present state of InSAR technology can provide improved monitoring of aquifer-system compaction and constraints on groundwater flow and aquifer-system compaction models, but InSAR currently is under-utilized in hydrogeologic characterizations of basin-fill alluvial aquifer systems. The future of InSAR in hydrogeology likely includes new operational and research applications that will improve the evaluation of the sustainability and management of aquifer systems through integrated monitoring and analysis of groundwater level and land-surface changes, and will enhance understanding of the coupled hydromechanical responses of complex aquifer systems to natural and anthropogenic stresses.

Satellite-borne SAR sensors most commonly used in the past for making interferometric measurements were optimized for SAR imagery and not for interferometry. An important consequence is that the satellite orbital configurations and control are suboptimal, which results in a degraded quality of the resulting interferograms. Future sensors can be expected to improve upon this, making InSAR more generally applicable.

Two main developments will contribute to advancing future hydrogeologic applications:

1. New SAR sensors are becoming available that can support investigations at greater spatial detail and higher 
temporal resolution. The TerraSAR-X satellite scheduled for launch in October 2006, for example, will provide SAR data from an 11-day repeat orbit with a spatial resolution approaching $1 \mathrm{~m}$. This will allow investigations of more dynamic displacement processes, possibly including aquifer-hydraulic tests (e.g. pumping tests), or help localize discontinuities in the displacement field much more precisely. The ALOS-PALSAR instrument launched in January 2006 is an L-band SAR that will support InSAR studies over thinly-to-moderately vegetated terrain where C-band InSAR is severely limited. Both of these recent missions are specifically designed to support InSAR-applications. Any image pair acquired on the same orbital path will, therefore, in principle, be suitable for interferometry - though the fundamental limits owing to temporal decorrelation remain an issue

2. Displacement observations from interferometric techniques will be more commonly considered in monitoring, characterization, and modeling of aquifer systems

Perhaps the most pertinent and imminent future application of InSAR is in identifying and enhancing the characterization of basins at risk for ground failures (earth fissures, surface faults) and unrecognized mining of the 'water of compaction' owing to groundwater overdraft. These hazards and others associated with the development of groundwater resources (e.g. Holzer and Galloway 2005) challenge our concepts of the sustainability of a groundwater resource. To address these potential hazards, the future will likely include more use of InSAR as a component in integrated monitoring and in the analysis of groundwater management strategies.

Though some capability to track groundwater levels and water use exists for many aquifers, there is limited ability to understand these data in the context of groundwater sustainability for most aquifer systems, and often an integrated approach with feedback among monitoring, scientific studies, numerical simulation, and resource management is lacking (Alley 2006). The integration of multiple satellite and ground-based technologies for monitoring regional land displacements improves accuracy, reliability, and the value of hydrogeologic information. Spirit leveling, GPS - differential and CORS (continuous operating reference station) InSAR, and PSI are incorporated in an integrated subsidence monitoring system for Venice, Italy. This combination is being used to overcome the limits associated with each technique and to provide improved mapping, monitoring, and insights into the controlling geologic, hydrologic, and anthropogenic factors (Teatini et al. 2005). An integrated ground-based monitoring approach in Houston, Texas that includes 13 borehole extensometers and regional groundwater level monitoring is being used by the Harris-Galveston Coastal Subsidence District to manage and mitigate land subsidence (Coplin and Galloway 1999; Galloway et al. 2003; Zilkoski et al. 2003). InSAR has been an important, recent addition to the integrated monitoring approach in Houston (Stork and Sneed 2002; Buckley et al. 2003) and the future application of PSI in Houston and other subsidenceaffected coastal areas - e.g. New Orleans (USA), Santa Clara Valley, Shanghai (China) and Venice - is especially promising. In these areas atmospheric effects and temporal decorrelation problems often limit InSAR. Although the statistical separation of motion and atmospheric signal contributions is a more typical element of PSI, this statistical technique also can be applied to InSAR data, provided a sufficient number of interferograms are available to support the statistical analysis.

The case studies demonstrate the utility of InSARderived displacement data used in concert with other hydrogeologic information to improve definition of the structural, depositional, and hydromechanical heterogeneity of thick alluvial aquifer systems, to delineate areas prone to earth fissures and residual compaction, to identify elastic and inelastic strain regimes, to define preconsolidation thresholds, and to provide estimates of some of the governing aquifer-system hydraulic properties $\left(S_{\mathrm{ke}}\right.$ and $K_{\mathrm{v}}$ ). It is anticipated that future applications of InSAR and PSI will continue to improve upon the definition of hydrogeologic framework models, and thereby improve resource assessments and potentially, sustainable development of these systems. Increasingly, numerical groundwater flow and aquifer-system compaction models are becoming an important tool resource managers can use to predict system responses to alternative management strategies (e.g. Sneed and Galloway 2000; Danskin et al. 2003; Phillips et al. 2003; Halford et al. 2005). InSAR can be used to constrain and improve these models (e.g. Hoffmann et al. 2003a). Because the time constants of these systems typically can be decades or longer, the ability to constrain these systems using SAR data available since 1992 is limited. As more SAR data suitable for interferometry become available, better models, predictions and management can result.

Other promising future hydrogeologic applications of SAR interferometry include: (1) evaluating horizontal deformation in aquifer systems (e.g. Burbey 2001a,b, 2002, 2005; Hoffmann and Zebker 2003); (2) identifying and accounting for displacements attributed to aquifersystem deformation measured in tectonic monitoring networks (e.g. Bawden et al. 2001); and (3) identifying spatial and temporal characteristics of deformation associated with focused groundwater recharge (e.g. Lu and Danskin 2001). Each of these applications can benefit when SAR interferometry is used as a component in an integrated assessment that includes other geodetic and hydrogeologic measurements and information.

PSI can contribute to each of the future hydrogeologic applications discussed above and should enhance capabilities to detect and monitor ground displacements in agricultural areas and other areas where InSAR is limited by poor temporal coherence. PSI has been more widely applied in Europe and many potential applications exist in North America and elsewhere.

Depletion of groundwater storage accompanying the utilization of groundwater resources is a global problem, as evidenced by the widespread and large-scale lowering 
of groundwater levels. The consequences may include degraded water quality, reduced surface-water flows and storage, damages to wetland, riparian and aquatic ecosystems, increased production costs, and land subsidence, often with accompanying ground-surface fissuring and faulting. In some coastal regions subject to flooding such as Houston, Texas and Santa Clara Valley, California land subsidence is one of the principal constraints on the use of groundwater resources and, consequently, a major concern for groundwater management (Wilson and Gorelick 1996; Coplin and Galloway 1999; Galloway et al. 2003; Ingebritsen and Jones 1999). Satellite-borne SAR interferometry, particularly InSAR, enhances our capabilities to map, monitor, analyze, simulate, and manage aquifersystem compaction and land subsidence at regional and local scales. Future applications of SAR interferometry in hydrogeology will likely address many pressing operational and scientific issues involved in improving the management of water resources in groundwater basins susceptible to aquifer-system compaction and land subsidence.

Acknowledgments The authors gratefully acknowledge Gerald W. Bawden, John W. Bell, Thomas J. Burbey, Peter M. Martin and Francis S. Riley whose reviews and comments greatly improved the manuscript. Any errors of commission or omission are the sole responsibility of the authors. This work was supported by the US Geological Survey and the German Aerospace Center.

\section{References}

Alley WM (2006) US groundwater: reserves for the future? Environment 48(3)11:25

Amelung F, Galloway DL, Bell JW, Zebker H (1999) Sensing the ups and downs of Las Vegas: InSAR reveals structural control of land subsidence and aquifer-system deformation. Geology 27 (6):483-486

Bawden GW, Thatcher W, Stein RS, Hudnut K (2001) Tectonic contraction across Los Angeles after removal of groundwater pumping effects. Nature 412:812-815

Bawden GW, Sneed M, Stork SV, Galloway DL (2003) Measuring human-induced land subsidence from space. USGS Fact Sheet 069-03. http://pubs.usgs.gov/fs/fs06903/. Cited 29 Sept 2006

Beaver J, Tatlow M, Cohen D, Marra M (2005) Monitoring subsidence trends in Phoenix with SAR interferometry. EOS TransAGU Fall Meet Suppl 86(52), abstract G51C-0852

Bell JW, Price JG (1991) Subsidence in Las Vegas Valley, 1980-91. Open-File Rep 93-5, Nevada Bureau of Mines and Geology, Reno, NV

Bell JW, Amelung F, Ramelli AR, Blewitt G (2002) Land subsidence in Las Vegas, Nevada, 1935-2000: New geodetic data show evolution, revised spatial patterns, and reduced rates. Environ Eng Geosci 8(3):155-174

Buckley SM, Rosen PA, Hensley S, Tapley BD (2003) Land subsidence in Houston, Texas, measured by radar interferometry and constrained by extensometers. J Geophys Res 108 (B11):2542. DOI 10.1029/2002JB001848. Cited 18 October 2006

Burbey TJ (2001a) Stress-strain analyses for aquifer-system characterization. Ground Water 39(1):128-136

Burbey TJ (2001b) Storage coefficient revisited: Is purely vertical strain a good assumption? Ground Water 39(3):458-464

Burbey TJ (2002) The influence of faults in basin-fill deposits on land subsidence, Las Vegas, Nevada, USA. Hydrogeol J 10 (5):525-538
Burbey TJ (2005) Use of vertical and horizontal deformation data with inverse models to quantify parameters during aquifer testing. Proceedings of the 7th International Symposium on Land Subsidence, vol 2, Shanghai, 23-28 Oct. 2005 Shanghai Scientific and Technical Publishers, pp 560-569

Canuti P, Casagli N, Farina P, Marks F, Ferretti A, Menduni G (2005) Land subsidence in the Arno River Basin studied through SAR interferometry. Proceedings of the 7th International Symposium on Land Subsidence, vol 1, Shanghai, 23-28 Oct 2005, Shanghai Scientific and Technical Publishers, pp 407-416

Catchings RD, Goldman MR, Gandhok G, Rymer MJ, Underwood DH (2000) Seismic imaging evidence for faulting across the northwestern projection of the Silver Creek Fault, San Jose, California. USGS Open-File Repo 00-125. http://pubs.er.usgs. gov/usgspubs/ofr/ofr00125. Cited 29 Sept 2006

Colesanti C, Ferretti A, Novali F, Prati C, Rocca F (2003) SAR monitoring of progressive and seasonal ground deformation using the permanent scatterers technique. IEEE Trans Geosci Remote Sens 4(7):1685-1701

Coplin LS, Galloway D (1999) Houston-Galveston, Texas: managing coastal subsidence. In: Galloway D, Jones DR, Ingebritsen SE (eds) Land subsidence in the United States. USGS Circular 1182, pp 35-48. http://pubs.usgs.gov/circ/circ1182/. Cited 29 Sept 2006

Danskin WR, Kasmarek MC, Strom EW (2003) Optimal withdrawal of elastically stored ground water in the Chicot Aquifer, Houston area, Texas. In: Prince KR, Galloway DL (eds) US Geological Survey Subsidence Interest Group Conference, Proceedings of the technical meeting, Galveston, Texas, 2729 November 2000, USGS Open-File Rep 03-308, pp 39-48. http://pubs.usgs.gov/of/2003/ofr03-308/pdf/OFR03-308.pdf. Cited 29 Sept 2006

Dutcher LC, Garrett AA (1963) Geologic and hydrologic features of the San Bernardino Area, California. USGS Water Suppl Pap 1419. http://pubs.er.usgs.gov/usgspubs/wsp/wsp1419. Cited 29 Sept 2006

Epstein VJ (1987) Hydrologic and geologic factors affecting land subsidence near Eloy, Arizona. USGS Water Resour Invest Rep 87-4143, http://pubs.er.usgs.gov/usgspubs/wri/wri874143. Cited 29 Sept 2006

Ferretti A, Prati C, Rocca F (2000) Nonlinear subsidence rate estimation using permanent scatterers in differential SAR interferometry. IEEE Trans Geosci Remote Sens 38:2202-2212

Ferretti A, Prati C, Rocca F (2001) Permanent scatterers in SAR interferometry. IEEE Trans Geosci Remote Sens 39(1):8-20

Ferretti A, Novali R, Bürgmann R, Hilley G, Prati C (2004) InSAR permanent scatterer analysis reveals ups and downs in the San Francisco Bay Area. EOS 85(34):317-324

Fram MS, Bergouse JK, Bergamaschi BA, Fujii R, Goodwin KD, Clark JF (2002) Water-quality monitoring and studies of the formation and fate of trihalomethanes during the third injection, storage, and recovery test at Lancaster, Antelope Valley, California, March 1998 through April 1999. USGS Open-File Rep 02-102. http://pubs.usgs.gov/of/2002/ofr02102/. Cited 29 Sept 2006

Fruneau B, Sarti F (2000) Detection of ground subsidence in the city of Paris using radar interferometry: isolation of deformation from atmospheric artifacts using correlation. Geophys Res Lett 27(24):3981-3984. DOI 10.1029/2000GL008489

Galloway DL, Hudnut KW, Ingebritsen SE, Phillips SP, Peltzer G, Rogez F, Rosen PA (1998) Detection of aquifer-system compaction and land subsidence using interferometric synthetic aperture radar, Antelope Valley, Mojave Desert, California. Water Resour Res 34:2573-2585

Galloway DL, Bürgmann R, Fielding E, Amelung, F, Laczniak RL (2000a) Mapping recoverable aquifer-system deformation and land subsidence in Santa Clara Valley, California, USA, using space-borne synthetic aperture radar. Proceedings of the 6th International Symposium on Land Subsidence, vol 2, Ravenna, Italy, 24-29 Sept 2000, National Research Council of Italy (CNR), pp 229-236 
Galloway DL, Jones DR, Ingebritsen SE (2000b) Measuring land subsidence from space. USGS Fact Sheet 051-00. http://pubs. usgs.gov/fs/fs-051-00/. Cited 29 Sept 2006

Galloway DL, Coplin LS, Ingebritsen SE (2003) Effects of land subsidence in the Greater Houston area. In: Agthe DE, Billings RB, Buras N (eds) Managing urban water supply, chap. 12. Kluwer, Dordrecht, The Netherlands, pp 187-203

Halford KJ, Laczniak RJ, Galloway DL (2005) Hydraulic characterization of overpressured tuffs in central Yucca Flat, Nevada Test Site, Nye County, Nevada. USGS Sci Invest Rep 20055211. http://pubs.usgs.gov/sir/2005/5211/. Cited 29 Sept 2006

Hanson RT (1989) Aquifer-system compaction, Tucson Basin and Avra Valley, Arizona. USGS Water Resour Invest Rep 88-4172. http://pubs.er.usgs.gov/usgspubs/wri/wri884172. Cited 29 Sept 2006

Hanson RT, Li Z, Faunt CC (2004) Documentation of the Santa Clara Valley regional ground-water/surface-water flow model, Santa Clara County, California. USGS Sci Invest Rep 20045231. http://pubs.usgs.gov/sir/2004/5231/. Cited 29 Sept 2006

Helm DC (1975) One-dimensional simulation of aquifer-system compaction near Pixley, California, 1. Constant parameters. Water Resour Res 11:465-478

Helm DC (1978) Field verification of a one-dimensional mathematical model for transient compaction and expansion of a confined aquifer system. Verification of Mathematical and Physical Models in Hydraulic Engineering, American Society of Civil Engineers Hydraulics Division Specialty Conference, 26th, University of Maryland, College Park, MD, 9-11 Aug 1978, pp 189-196

Heywood CE, Galloway DL, Stork SV (2002) Ground displacements caused by aquifer-system water-level variations observed using interferometric synthetic aperture radar near Albuquerque, New Mexico. USGS Water Resour Invest Rep 02-4235. http:// nm.water.usgs.gov/publications/abstracts/wrir02-4235.html. Cited 29 Sept 2006

Hoffmann J (2005) The future of satellite remote sensing in hydrogeology. Hydrogeol J 13:247-250. http://dx.doi.org/ 10.1007/s10040-004-0409-2

Hoffmann J, Zebker HA (2003) Prospecting for horizontal surface displacements in Antelope Valley, California, using satellite radar interferometry. J Geophys Res 108(F1):6011. http://dx. doi.org/10.1029/2003JF000055. Cited 18 Oct 2006

Hoffmann J, Galloway DL, Zebker HA, Amelung F (2001) Seasonal subsidence and rebound in Las Vegas Valley, Nevada, observed by synthetic aperture radar interferometry. Water Resour Res 37:1551-1566

Hoffmann J, Galloway DL, Zebker HA (2003a) Inverse modeling of interbed storage parameters using land subsidence observations, Antelope Valley, California. Water Resour Res 39(2): 1031. DOI 10.1029/2001WR001252

Hoffmann J, Leake SA, Galloway DL, Wilson AM (2003b) MODFLOW-2000 ground-water model-user guide to the subsidence and aquifer-system compaction (SUB) package. USGS Open-File Rep 03-233. http://pubs.usgs.gov/of/2003/ofr03-233/. Cited 29 Sept 2006

Holzer TL, Galloway DL (2005) Impacts of land subsidence caused by withdrawal of underground fluids in the United States. In: Ehlen J, Haneberg WC, Larson RA (eds) Humans as geologic agents. Rev Eng Geol 16:87-99

Hooper A, Zebker HA, Segall P, Kampes B (2004) A new method for measuring deformation on volcanoes and other natural terrains using InSAR persistent scatterers. Geophys Res Lett 31: L23611. DOI 10.1029/2004GL021737. Cited 18 Oct 2006

Ikehara ME, Phillips SP (1994) Determination of land subsidence related to ground-water level declines using global positioning system and leveling surveys in Antelope Valley, Los Angeles and Kern Counties, California, 1992. USGS Water Resour Invest Rep 94-4184. http://pubs.er.usgs.gov/usgspubs/wri/ wri944184. Cited 29 Sept 2006

Ikehara ME, Galloway DL, Fielding E, Bürgmann R, Lewis AS, Ahmadi B (1998) InSAR imagery reveals seasonal and longerterm land-surface elevations changes influenced by ground- water levels and fault alignment in Santa Clara Valley, California. EOS Trans AGU Fall Meet Suppl 79(45), abstract U21A-15

Ingebritsen SE, Jones DR (1999) Santa Clara Valley, California: a case of arrested subsidence. In: Galloway D, Jones DR, Ingebritsen SE (eds) Land subsidence in the United States. USGS Circular 1182, pp 15-22. http://pubs.usgs.gov/circ/ circ1182/. Cited 29 Sept 2006

Jachens RC, Wentworth CM, Graymer RW, McLaughlin RJ, Chuang FC (2002) A 40-km-long concealed basin suggests large offset on the Silver Creek fault, Santa Clara Valley, California. GSA Abstr Prog 34(5):A99

Kampes D (2005) Displacement parameter estimation using permanent scatterer interferometry. DLR-Forschungsberichte 16

Kircher M (2004) Analyse flächenhafter Senkungserscheinungen in sedimentären Gebieten mit den neuen Techniken der Radarfernerkundung am Beispiel der Niederrheinischen Bucht [Analysis of extensive subsidence in sedimentary areas with the new techniques of radar remote sensing using the example of the lower Rhine basin]. PhD Thesis, Universität Bonn, Germany. http://hss.ulb.uni-bonn.de/diss_online/math_nat_fak/2004/ kircher michaela/index.htm. Cited 19 Sept 2006

Laczniak RJ, Galloway DL, Sneed M (2003) InSAR detection of post-seismic and coseismic ground-surface deformation associated with underground weapons testing, Yucca Flat, Nevada Test Site, (abstract). In: Prince KR, Galloway DL (eds) US Geological Survey Subsidence Interest Group Conference, Proceedings of the technical meeting, Galveston, 27-29 Texas, November 2000. USGS Open-File Rep 03-308, pp 121-128. http://pubs.usgs.gov/of/2003/ofr03-308/. Cited 29 Sept 2006

Leake SA, Prudic DE (1991) Documentation of a computer program to simulate aquifer-system compaction using the modular finite-difference ground-water flow model. Techniques of Water-Resources Investigations, book 6, chap. A2, US Geological Survey. http://pubs.er.usgs.gov/usgspubs/twri/ twri06A2. Cited 29 Sept 2006

Leighton DA, Phillips SP (2003) Simulation of ground-water flow and land subsidence in the Antelope Valley ground-water basin, California. USGS Water Resour Invest Rep 03-4106. http:// pubs.usgs.gov/wri/wrir034016/text.html. Cited 29 Sept 2006

$\mathrm{Lu} \mathrm{Z}$, Danskin WR (2001) InSAR analysis of natural recharge to define structure of a ground-water basin, San Bernardino, California. Geophys Res Lett 28(13):2661-2664

McDonald MG, Harbaugh AW (1988) A modular three-dimensional finite-difference ground-water flow model. Techniques of WaterResources Investigations, book 6, chap. A1, US Geological Survey. http://pubs.usgs.gov/twri/twri6a1/. Cited 29 Sept 2006

Malmberg GT (1965) Available water supply of the Las Vegas ground-water basin, Nevada. USGS Water Suppl Pap 1780. http://pubs.er.usgs.gov/usgspubs/wsp/wsp1780. Cited 29 Sept 2006

Massonnet D, Feigl KL (1998) Radar interferometry and its application to changes in the Earth's surface. Rev Geophys 36 (4):441-500

Morgan DS, Dettinger MD (1996) Ground-water conditions in Las Vegas Valley, Clark County, Nevada, Part 2, Hydrogeology and simulation of ground-water flow. USGS Water Suppl Pap 2320B. http://pubs.er.usgs.gov/usgspubs/wsp/wsp2320B. Cited 29 Sept 2006

National Research Council (1991) Mitigating losses from land subsidence in the United States. National Academy Press, Washington, DC, p 58

Nolan M, Fatland DR, Hinzman L (2003) DInSAR measurement of soil moisture. IEEE Trans Geosci Remote Sens 41(12):28022813

NPA (2006) Ground stability (InSAR): applications and case studies, London, UK. http://www.npagroup.com/insar/apps/ london psi.htm. Cited 29 Sept 2006

Pavelko MT (2000) Ground-water and aquifer-system-compaction data from the Lorenzi Site, Las Vegas, Nevada, 1994-99. USGS Open-File Rep 00-362. http://pubs.er.usgs.gov/usgspubs/ofr/ ofr00362. Cited 29 Sept 2006 
Pavelko MT (2004) Estimates of hydraulic properties from a onedimensional numerical model of vertical aquifer-system deformation, Lorenzi Site, Las Vegas, Nevada. USGS Water Resour Invest Rep 03-4083. http://pubs.usgs.gov/wri/wri034083/. Cited 29 Sept 2006

Pavelko MT, Wood DB, Laczniak RJ (1999) Las Vegas, Nevada: gambling with water in the desert. In: Galloway D, Jones DR, Ingebritsen SE (eds) Land subsidence in the United States. USGS Circular 1182, pp 49-64. http://pubs.usgs.gov/circ/ circ1182/. Cited 29 Sept 2006

Pavelko MT, Hoffmann, J, Damar NA (2006) Interferograms showing land subsidence and uplift in Las Vegas Valley, Nevada, 1992-99. USGS Sci Invest Rep 2006-5218. http:// pubs.water.usgs.gov/sir2006-5218/. Cited 29 Sept 2006

Phillips SP, Carlson CS, Metzger LF, Howle JF, Galloway DL, Sneed M, Ikehara ME, Hudnut KW, King NE (2003) Analysis of tests of subsurface injection, storage, and recovery of freshwater in Lancaster, Antelope Valley, California. USGS Water Resour Invest Rep 03-4061. http://ca.water.usgs.gov/ pubs/wrir 03-4061.html. Cited 29 Sept 2006

Poland JF, Ireland RL (1988) Land subsidence in the Santa Clara Valley, California, as of 1982. USGS Prof Pap 497-F. http:// pubs.er.usgs.gov/usgspubs/pp/pp497F. Cited 29 Sept 2006

Poland JF, Lofgren BE, Ireland RL, Pugh RG (1975) Land subsidence in the San Joaquin Valley, California, as of 1972. USGS Prof Pap 437-H. http://pubs.er.usgs.gov/usgspubs/pp/ pp437H. Cited 29 Sept 2006

Ponti DJ (1985) The Quaternary alluvial sequence of the Antelope Valley, California. Geol Soc Am Spec Pap 203:79-86

Riley FS (1969) Analysis of borehole extensometer data from central California. In: Tison LJ (ed) Land subsidence. Int Assoc Sci Hydrol Publ 89(2):423-431

Riley FS (1998) Mechanics of aquifer systems: the scientific legacy of Joseph F. Poland. In: Borchers JW (ed) Land subsidence case studies and current research: proceedings of the Dr. Joseph F. Poland Symposium on Land Subsidence. Assoc Eng Geol Spec Publ 8:13-27

Rosen PA, Hensley S, Joughin IR, Li, FK, Madsen SN, Rodriguez E, Goldstein RM (2000) Synthetic aperture radar interferometry. Proc IEEE 88(3):333-382

Schmidt DA, Bürgmann R (2003) Time dependent land uplift and subsidence in the Santa Clara Valley, California, from a large InSAR data set. J Geophys Res 108(B9):2416. DOI 10.1029/ 2002JB002267. Cited 18 October 2006

Smith LC (2002) Emerging applications of interferometric synthetic aperture radar (InSAR) in geomorphology and hydrology. Ann Am Geogr 92(3):385-398

Sneed M, Galloway DL (2000) Aquifer-system compaction and land subsidence: measurements, analyses, and simulations:- ${ }^{-}$the Holly site, Edwards Air Force Base, Antelope Valley, California. USGS Water Resour Invest Rep 00-4015. http://ca.water. usgs.gov/archive/reports/wrir004015/. Cited 29 Sept 2006

Sneed M, Ikehara ME, Stork SV, Amelung F, Galloway DL (2003) Detection and measurement of land subsidence using interferometric synthetic aperture radar and global positioning system, San Bernardino County, Mojave Desert, California. USGS Water Resour Invest Rep 03-4015. http://pubs.usgs.gov/wri/ wri034015/. Cited 29 Sept 2006

Stork SV, Sneed M (2002) Houston-Galveston Bay area, Texas from space: a new tool for mapping land subsidence. USGS Fact
Sheet 110-02. http://pubs.usgs.gov/fs/fs-110-02/. Cited 29 Sept 2006

Teatini P, Tosi L, Strozzi T, Carbognin L, Wegmüller U, Rizzetto F (2005) Mapping regional land displacements in the Venice coastland by an integrated monitoring system. Rem Sens Env 98. DOI 10.1016/j.rse.2005.08.002. Cited 18 Oct 2006

Terzaghi K (1925) Erdbaumechanik auf bodenphysikalisher Grundlage [Earthworks mechanics based on soil physics]. Deuticke, Vienna, Austria

Tolman CF, Poland JF (1940) Ground-water infiltration, and ground-surface recession in Santa Clara Valley, Santa Clara County, California. Trans Am Geophys Union 21:23-34

Usai S (2001) A new approach for long term monitoring of deformations by differential SAR interferometry, $\mathrm{PhD}$ Thesis, Technische Universiteit Delft, The Netherlands

Valentine DW, Densmore JN, Galloway DL, Amelung F (2001) Use of InSAR to identify land-surface displacements caused by aquifer-system compaction in the Paso Robles area, San Luis Obispo County, California, March to August 1997. USGS Open-File Rep 00-447. http://pubs.usgs.gov/of/2000/ofr00-447/. Cited 29 Sept 2006

Vincent P, Larsen S, Galloway D, Laczniak RJ, Walter WR, Foxall W, Zucca JJ (2003) New signatures of underground nuclear tests revealed by satellite radar interferometry. Geophys Res Lett 30(22):2141. DOI 10.1029/2003GL018179

Watson KM, Bock Y, Sandwell DT (2002) Satellite interferometric observations of displacements associated with seasonal groundwater in the Los Angeles Basin. J Geophys Res 107. DOI 10.1029/2001JB000470. Cited 18 October 2006

Williams RA, Stephenson WJ, Wentworth CM, Odum JK, Hanson RT, Jachens RC (2002) Definition of the Silver Creek Fault and Evergreen Basin sediments from seismic reflection data, San Jose, California. EOS Trans AGU Fall Meet Suppl 83(47), abstract T71E-1207

Wilson AM, Gorelick S (1996) The effects of pulsed pumping on land subsidence in the Santa Clara Valley, California. J Hydrol 174:375-396

Worawattanamateekul J, Hoffmann J, Adam N, Kampers, B, Altermann W (2004) Radar interferometry technique for urban subsidence monitoring: a case study in Bangkok and its vicinity. ENVISAT Symposium 2004, Salzburg, Austria, 6-10 Sept 2004

Wright TJ, Parsons BE, Lu Z (2004) Toward mapping surface deformation in three dimensions using InSAR. Geophys Res Lett 31:L01607. DOI 10.1029/2003GL018827. Cited 18 Oct 2006

Zebker HA, Goldstein R (1986) Topographic mapping from interferometric SAR observations. J Geophys Res 91:49935001

Zebker HA, Rosen PA, Hensley S (1997) Atmospheric effects in interferometric synthetic aperture radar surface deformation and topographic maps. J Geophys Res 102(B10):7547-7563

Zilkoski DB, Hall LW, Mitchell GJ, Kammula V, Singh A, Chrismer WM, Neighbors RJ (2003) The Harris-Galveston Coastal Subsidence District/National Geodetic Survey Automated GPS Subsidence Monitoring Project. In: Prince KR, Galloway DL (eds) US Geological Survey Subsidence Interest Group Conference, proceedings of the technical meeting, Galveston, Texas,27-29 November 2000. USGS Open-File Rep 03-308, pp 13-26. http://pubs.usgs.gov/of/2003/ofr03-308/pdf/OFR03-308. pdf. Cited 29 Sept 2006 